\title{
A contemporary review of large-scale non-standard structural fire testing
}

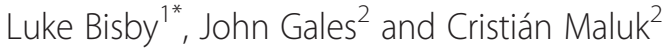

\begin{abstract}
In recent years, large-scale structural fire testing has experienced something of a renaissance. After about a century with the standard fire resistance test being the predominant means to characterize the response of structural elements in fires, both research and regulatory communities are confronting the many inherent problems associated with using simplified single element tests, on isolated structural members subjected to unrealistic temperature-time curves, to demonstrate adequate structural performance in fires. As a consequence, a shift in testing philosophy to large-scale non-standard fire testing, using real rather than standard fires, is growing in momentum. A number of custom made, non-standard testing facilities have recently been constructed or are nearing completion. Non-standard fire tests performed around the world during the past three decades have identified numerous shortcomings in our understanding of real building behavior during real fires; in most cases these shortcomings could not have been observed through standard furnace tests. Supported by a grant from the Fire Protection Research Foundation, this paper presents a review of relevant non-standard structural fire engineering research done at the large-scale around the world during the past few decades. It identifies gaps and research needs based both on the conclusions of previous researchers and also on the authors' own assessment of the information presented. A review of similar research needs assessments carried out or presented during the past ten years is included. The overarching objective is to highlight gaps in knowledge and to help steer future research in structural fire engineering, particularly experimental research at the large-scale.
\end{abstract}

Keywords: Fire resistance, Standard fire testing, Large-scale, Non-standard fires, Natural fires

\section{Introduction and objectives}

In 1981, pioneering fire engineer Margaret Law presented a paper at the ASCE Spring Convention in New York entitled "Designing fire safety for steel - recent work" (Law 1981). This paper presented a summary of work that she and colleagues at Arup Fire had completed to performance-engineer the structural fire safety of innovative and architecturally exciting buildings, for instance the Pompidou Centre in Paris. Among the topics covered in this paper, Law stated a number of criticisms of the standard fire resistance test and proposed a way forward using knowledge-based analytical approaches. Paraphrasing, Law's key criticisms (in the context of fire resistance testing of protected steel elements) were that:

\footnotetext{
* Correspondence: luke.bisby@ed.ac.uk

${ }^{1}$ Arup Professor of Fire and Structures, BRE Centre for Fire Safety Engineering, The University of Edinburgh, UK EH9 3J
}

Full list of author information is available at the end of the article
1. the standard temperature-time curve is not representative of a real fire in a real building indeed it is physically unrealistic and contradicts available knowledge of fire dynamics;

2. the required duration of fire exposure in the standard test (or the time-equivalent exposure) is open to criticism on a number of grounds and should be revisited;

3. the loading and end conditions in the standard test are not well defined - and clearly cannot represent the continuity, restraint, redistribution, and membrane actions in real buildings; and

4. the structural properties of the test specimen at room temperature are not well defined.

Many within the fire testing community will argue that standard furnace testing has advantages in terms of control and reproducibility, and that it is therefore useful for comparative testing and benchmarking. The authors 
agree with this view up to a point. However in the current paper we prefer the stance taken by Harmathy and Lie (Harmathy and Lie 1970), who rightly noted that "it always must be borne in mind that in a strict sense standard fire endurance (testing) is not a measure of the actual performance of an element in fire, and, furthermore, that it is not even a perfect measure for comparison". This key point appears to have been largely forgotten by the testing community, and a central purpose of the current paper is to show that the latter view is the more correct. A secondary purpose of the current paper is to show that a move away from standard furnace testing as the means to certify (and design) buildings to resist the effects of fires offers potential opportunities for improved efficiencies and enhanced sustainability in building construction, while it also offers a genuine hope of preventing unforeseen failures as the building construction industry implements additional optimization and innovation.

Now more than three decades after Law's paper was published, the Structural Fire Engineering (SFE) community continues to base the vast majority of its guidance and regulatory compliance requirements on standard fires and the standard fire resistance test (e.g. ASTM 2011, ISO 1999). A notable exception to this is in the use of so-called natural fires and performance-based objectives in the design and analysis of steel-framed buildings in Europe (Corus 2006). The fact remains, however, that the SFE community is only just beginning to truly wrestle with the true response of real structures (other than composite steel frames) in real fires. This is perhaps a consequence of the events of September 11, 2001, along with several other notable structural failures during fires (see Beitel and Iwankiw 2008). It has also been repeatedly noted in recent years that when structures do (rarely) fail in fires it is usually for reasons that would not (or could not) have been expected on the basis of standard furnace testing.

Structural fire testing is thus experiencing something of a renaissance. After more than a century with the standard fire resistance test being the predominant means to characterize the response of structural elements in fires, both the research and regulatory communities are now confronting the many inherent problems associated with using simplified single element tests, on isolated structural members subjected to unrealistic temperature-time curves, to demonstrate adequate structural performance in real fires. A gradual shift in testing philosophy to large-scale nonstandard fire testing, using real rather than standard fires, is underway and a number of custom made non-standard testing facilities have recently come on line or are nearing completion (e.g. NIST 2011).

It is also noteworthy that all modern structural fire design uses detailed computer analysis for both fire and structural modelling during fire. One important purpose of large scale tests is to allow the calibration of these computer models, which can then be used to explore a wide range of other possible scenarios; this applies to both fire modelling and structural modelling.

With the above points in mind, the objectives of the current paper are:

- to provide an awareness of the numerous shortcomings of historical structural fire testing procedures which currently dominate the structural fire engineering community;

- to review SFE research needs assessments carried out or presented in the in the past ten years;

- to review the several dozen large-scale, nonstandard fire tests conducted globally during the past three decades, to show what issues have been studied and what general conclusions can be drawn;

- to offer critical analysis of available experimental data and knowledge on large-scale non-standard fire resistance tests, and available structural testing facilities and capabilities; and

- to provide recommendations for future structural fire resistance testing and research.

\section{Previous reviews and research needs assessments}

Before presenting a review of available information on large-scale, non-standard fire, it is worthwhile to review previously published reviews, focused on this or similar issues, during recent years. A number of such reviews are available in the literature, and these are presented chronologically below.

\section{British Steel (1999)}

A comprehensive research report entitled "The Behaviour of Multi-Storey Steel Framed Buildings in Fire" was published by British Steel (1999). While the central purpose of the report is to summarize the results of six large-scale fire tests carried out at Cardington during 1995-1996 (described in detail below), the report also provides descriptions of the impacts of two real fires in real steel framed buildings the Broadgate Fire of 1990 and the Churchill Plaza Fire of 1991 (British Steel 1999). The report also gives short summaries of prior large-scale non-standard structural fire tests performed on steel framed buildings, including the Australian BHP William Street and Collins Street Fire Tests (circa 1990), and a large structural fire test performed at Stuttgart-Vaihingen University, Germany in 1985 (discussed below).

The main conclusion was that, in steel framed buildings with steel-concrete composite slabs, the composite floor and supporting steelwork have a profound influence on the stability of the structure and that diaphragm and membrane actions, which are impossible to properly evaluate using single span furnace tests, should be 
considered and may considerably improve the fire resistance. These conclusions apparently formed the basis for the subsequent design and construction of the Cardington test building discussed in Section 3 of this paper.

\section{Grosshandler (2002) - NISTIR 6890}

In February 2002 the US National Institute of Standards and Technology's (NIST) Building and Fire Research Laboratory (BFRL) held a meeting of engineering and scientific experts in materials, fire protection, and structural design with the purpose of identifying the research required to underpin meaningful tests and predictive methods for use in evaluating the performance of structures subject to real fires. The specific objectives of the workshop were (Grosshandler 2002): to review current practices for achieving fire resistance; to explore the promise of fire dynamics simulations and structural behavior predictions at elevated temperatures; to identify new fire resistance options coming from materials science; to identify opportunities and needs in advanced computational methods; and to identify applications and needs for emerging measurement, instrumentation and test methods. The resulting recommendations which are directly relevant to large-scale structural fire testing, and which speak to some of the shortcomings of standard furnace testing, include (Grosshandler 2002):

- developing new experimental methods for measuring high temperature thermal and mechanical properties of structural and insulating materials, which are not well known for many newer construction materials;

- developing experimental facilities and capabilities for measuring the behavior of real-scale connections and assemblies under controlled fires that permit extrapolation to total building frame behavior up to the point of failure, which cannot be done using standard fire testing furnaces; and

- establishing as a goal the need to predict the performance of coupled building systems at elevated temperatures to the point of impending failure, rather than simply assessing the performance of isolated structural elements in testing furnaces up to some pre-defined failure criterion which may or may not represent impending failure.

\section{Grosshandler (2003)}

The International FORUM of Fire Research Directors published a position paper (Grosshandler 2003) on the evaluation of structural fire resistance in 2003. This paper was written in the wake of the September 11, 2001 collapses of WTC buildings 1, 2, and 7, and it focused on needs for designing structures for total burnout of the fuel load while considering full structure response to fire (as opposed to considering isolated elements). The paper discusses some of the inherent problems with a prescriptive approach to structural fire safety design and is critical of current standard test methods for characterization of structural response to fire. It also suggests that future research is necessary in support of the development of rational, performance-based structural fire design codes. The main points expressed can be summarized as follows (after Grosshandler 2003):

- Current structural fire resistance test methods must be revised to address: (1) the response of structural elements up to ultimate failure rather than simply up to same pre-imposed fire resistance time; (2) the variability, and hence statistical uncertainty, of the various failure modes to be expected; and (3) an alternative fire rating system in units other than time.

- The capabilities and limitations of standard fire resistance test methods and computational tools must become more apparent to all members of the fire safety design, regulation, and fire and rescue communities.

- The prediction of the performance of coupled building systems to the point of impending failure in a fire should be established as a goal for the building industry.

- An international research effort is needed to move towards performance-based structural fire resistance design and to develop: (1) a comprehensive, high temperature database of the thermal and mechanical properties of building materials; and (2) facilities beyond the current state-of-the-art for experimental methods and protocols for measuring the response of structural connections when exposed to fire, as well as entire building frames.

\section{Almand et al. (2004) - NISTIR 7133}

Almand et al. (2004) present a report entitled "NISTSFPE Workshop for Development of a National R\&D Roadmap for Structural Fire Safety Design and Retrofit of Structures: Proceedings," which was also developed in the wake of the September 11, 2001 collapses. The report represents the views of more than sixty leading thinkers in the structural fire safety engineering community and contains numerous recommendations for improvements to structural fire safety engineering design and practice. In particular, the report identifies five noteworthy deficiencies of building fire safety design practice (these still apply to current practice in 2013, and echo the deficiencies noted by Law (1981)):

1. Standard fire resistance methods stipulate a prescribed time-temperature exposure and are 
adequate to compare relative performance of structural components; however they do not provide information on the actual performance of a component in a real fire.

2. The role of connections, diaphragms, and multiple load paths in maintaining overall structural integrity during fire is ignored in structural fire design. Structural fire protection design methods are (generally) based on fire endurance tests of single elements and do not (typically) account for the behavior of connections or of the entire structure as a whole.

3. Analytical tools are currently inadequate to evaluate the effectiveness of alternative design and fire protection strategies to enhance structural fire endurance. No practical tools exist that couple fire dynamics to the structural system response.

4. Fire hazards to structures need to be better modelled and predicted to develop design criteria for both internal and external fires. This includes: (1) deterministic and probabilistic models for specifying the magnitude, location, and spatial distribution of fire hazards on structures; (2) determination of reliability-based load factors for combined dead, live, and fire loads and resistance factors for loss in structural strength and stiffness; and (3) methods for load and resistance factor design (LRFD) under fire conditions.

5. There is a lack of knowledge about the fire behavior of structures built with innovative structural or fire protection materials (application of innovative structural techniques and systems but making use of conventional materials should probably also be added here).

The key conclusions from this workshop relevant to the current discussion can be summarized as follows (after Almand et al. 2004):

- Research-quality laboratory and real building data are badly needed. This requires construction and use of large-scale structural fire test facilities and better knowledge of engineering material properties at elevated temperature and performance of structural components under load during fire.

- Performance goals, criteria and methodologies are required for implementation in codes and standards, including quantification of safety provided by current prescriptive and performance-based methods, practice guidelines for the enforcement and engineering communities, development of a risk-based methodology for design fires, benchmark problems for validation of analysis tools (e.g. Gillie 2009), standardized test methods, and limit states and failure criteria.
Beyler et al. (2007) - NIST GCR 07-910

Beyler et al. (2007) present a report entitled "Fire Resistance Testing for Performance-based Fire Design of Buildings". This report seeks to identify the needed capabilities of a standard fire resistance test to support performance-based structural fire engineering in the United States, and to move SFE toward rational engineering of fire protection rather than relying on prescriptive requirements. It is noteworthy that this report was apparently written with an explicit intent to modify or enhance single element structural fire resistance testing using standard testing furnaces by improving the level of information and understanding that they might yield. Recommendations are made with respect to:

1. furnace instrumentation, for instance a transition to plate thermometers for furnace control, as has already been implemented in Europe (note that the use of plate thermometers improves consistency between test furnaces but does not totally address this issue);

2. furnace operation, for instance a new temperature time curve (which rises rapidly to $1200^{\circ} \mathrm{C}$ and thereafter remains constant) is proposed as an upper bound to available data from compartment tests (whether an upper bound to the available compartment test data makes sense as a credible worst case design fire is doubtful);

3. structural instrumentation, for instance the true restraining force imposed during tests should be measured using load cells, and strain gauges should be used at critical locations; however it should be noted that strain gauges are notoriously unreliable during fire tests, a factor which the authors of the report seem unaware, and measuring restraining forces is far from straightforward in practice; and

4. structural operations, for instance it is proposed that all structural elements should be tested until failure, rather than to an arbitrary end-point based on temperature, fire rating, deflection, or deflection rate, so that the actual failure times, loads, and (most importantly) mechanisms can be properly observed.

\section{Kodur et al. (2007) - NIST GCR 07-915}

Kodur et al. (2007) present the outcomes of a "National Workshop on Structures in Fire: State-of-the-Art, Research and Training Needs," held at Michigan State University in June 2007. The report has also been slightly modified and presented as a journal publication (Kodur et al. 2011). The key objective of the workshop upon which the report is based was apparently "to enhance the research and training activities in the fire safety area by identifying the needs for research and for state-of 
-the-art improvement" (Kodur et al. 2007). The specific objectives were: to review the state-of-the-art in structural fire safety, to identify and prioritize research needs, to improve education and training in the US, and to develop plans to improve provisions in codes and standards. Only the issues directly relevant to structural fire experiments are discussed herein.

In discussing the state-of-the-art in fire experiments, Kodur et al. (2007) note the serious drawbacks of standard furnace tests which are limited to tests on isolated structural elements. The resulting paucity of good experimental data and lack of properly validated models capable of predicting the real fire response of a structural system through the entire range of relevant behaviors are noted. Also it is claimed that, within the area of fire science and engineering, structural fire safety is the least developed area.

Kodur et al. (2007, 2011) comment on a lack of high temperature material properties and constitutive relationships (with a particular emphasis on high strength concrete and fire insulating materials) and on the drawbacks of standard fire test procedures stated by Law (1981); i.e. the fires have no decay phase and are physically unrealistic, structural interactions with adjacent framing are ignored, unknown and perhaps unrealistic load levels and restraint conditions are imposed. They note that current test methods and acceptance criteria give insufficient consideration to various limit states (i.e. limit states other than collapse) and that fire resistance tests on isolated elements generally consider only a limited number of parameters.

With respect to available information from large-scale non-standard structural fire tests, Kodur et al. (2007, 2011) note that a small number of tests on portal frames were conducted in the 1980's and 90's, however references to the resulting test reports are not provided. The Cardington tests by the Building Research Establishment (BRE) in the UK during the 1990s (British Steel 1999) are also briefly noted.

Research needs for structural fire experiments noted by Kodur et al. (2007) are (previously stated by Beyler et al. (2007) in most cases):

- Development of high-temperature constitutive material models and reliable input data for computational models to understand system response to fire and possible failure modes.

- Development of new and more reliable sensor technology (e.g. strain gauges, heat flux gauges, deflection gauges) to measure thermal and structural response parameters during fire tests.

- Collection and generation of test data for model verification and validation, particularly for modeling full structure response to fire and adequately predicting failure modes.
- Undertaking full-scale fire tests on decommissioned buildings to provide real data for model validation.

- Characterizing connection behavior in fire, since connections are noted as 'significantly influencing' the response of structural systems during fire.

- Improving procedures and specifications to modify standard fire tests including installation of additional instrumentation to capture detailed structural response, testing up to a failure limit state rather than a predefined end point, consideration of all failure limit states, and specifications on pre-test property measurements.

\section{Beitel and Iwankiw (2008) - NIST GCR 02-843-1 (Revision)}

A report by Beitel and Iwankiw (2008) was commissioned by NIST and completed in 2002 but was republished in 2008 with minor revisions. The purpose of the report was to analyze the needs and existing capabilities for full-scale fire resistance testing of structural connections, and consists of a survey of historical information on occurrences of fire in multi-story buildings which resulted in structural collapse. It also includes a survey of facilities capable of structural testing of building elements under fire (furnace) conditions, and an assessment of the needs for additional testing and/or experimental facilities to allow the performance of structural assemblies and fire resistance materials to be predicted under extreme fire conditions within actual buildings (Beitel and Iwankiw 2008).

The report contains descriptions of 22 cases where multi-storey buildings experienced fire-induced collapses between 1970 and 2002, with approximately equal distribution between steel, concrete, and masonry buildings, and with the majority of fires in office or commercial buildings. Specific details of the various collapses are omitted here. However, the following statements can be made on the basis of the information presented:

1. in most cases the critical failure modes observed in real buildings could not have been predicted on the basis of standard fire resistance (furnace) testing;

2. structural interactions and connection response played important roles in all cases; and

3. in several cases the collapses occurred during the cooling phase of the fire.

The report notes that "connections are generally recognized as the critical link in the collapse vulnerability of all structural framing systems, whether or not fire is involved". Also presented is a review of high-rise building fires without collapses, but with major structural damage, which leads to the suggestion that further work on the structural fire response of entire building frames should be conducted for both steel and concrete construction. 
The final contribution of this report is to present a global survey of structural fire resistance testing capability, essentially by surveying fire research and testing laboratories around the world as to their capabilities with respect to both vertical and horizontal structural elements. The focus appears to be on structural fire testing capabilities involving furnace testing, as opposed to tests using real fires. Based on the responses, the authors conclude that many laboratories are able to perform standard furnace fire resistance tests of various sizes, types of fire exposure (heating but not necessarily controlled cooling), loading, and measurements. They note that several unusually large furnaces exist and that these could be used to evaluate structural connections or combinations of building elements, however they also note that no single laboratory is currently able to test large-scale structural assemblies under the full range of applicable loading and fire exposure conditions.

Beitel and Iwankiw (2008) also provide a needs assessment for structural fire testing, which they begin by highlighting the limitations of standard fire resistance testing, all of which have already been noted above and widely acknowledged since the late 1970s. The major research needs noted include (paraphrasing and with considerable repetition from reports already presented):

- developing a better understanding of the interactions between structural elements and the thermally-induced loadings in a building during fire;

- understanding opportunities for load redistribution and alternative load paths in buildings to prevent global failure;

- demonstrating the performance and robustness of connections in fire;

- investigating the impacts of multiple floor fires and heating of elements from both sides;

- performing fire tests on elements of realistic scale, particularly large members with long spans;

- developing better instrumentation for use during fire tests;

- understanding and demonstrating the reliability of structural fire protection materials; and

- development of a unique testing facility to accommodate the required size, appropriate loading and the fire exposures needed for longer, wider or taller members.

\section{Other reviews}

As part of the European Cooperation in Science and Technology (COST) Action TU0904: Integrated Fire Engineering and Response Working Group, a summary of available large-scale structural fire tests conducted globally was presented by Frantisek Wald at a COST Action TU0904 Working Group meeting in April 2011 (Wald
2011). This paper presents a summary, with source references and brief descriptions, of a number of large-scale non-standard furnace tests, all of which are described in the following sections. However, the report provides little insight into the key conclusions from the fire tests, nor does it discuss knowledge gaps or research needs.

Vassart and Zhao (2011) produced an 'Engineering Background Document' as part of an EU Commission-funded Leonardo Da Vinci project on "Fire Resistance Assessment of Partially Protected Composite Floors (FRACOF)." The document includes detailed summaries of a number of large-scale non-standard structural fire resistance tests performed in Europe, including the Cardington tests (see below) and tests on open, steel-framed car parks performed in France (also discussed below). It also includes evidence from real fires at Broadgate and Churchill Plaza, and from small-scale fire resistance tests performed at the University of Manchester (Bailey and Toh 2007). Few insights are presented however.

\section{Large-scale non-standard tests}

The current review is interested in modern era large-scale, non-standard structural fire resistance testing, with a particular emphasis on experiments aimed at better understanding the full-structure response of real buildings in real fires. In general, the review is focused on tests which have used real fires rather than testing furnaces to provide the thermal insult to the tested assembly. However, in some cases furnaces have been used to perform structural fire resistance tests which clearly fall outside the scope of typical standard fire testing procedures, and some of these have been included. In performing this review, more than 30 individual large-scale tests have been identified since the early 1980s, although in some cases (as in the case of the Cardington steel frame tests) multiple tests were performed and reported over a period of months or years in a single test structure. The following sections present overviews of the available test reports and common themes are identified wherever possible. The tests are categorized chronologically and based on the primary materials of construction.

In an effort to provide a coherent framework within which to consider the various tests presented in the following sections, Figure 1 provides a 'crudeness framework' which categorizes possible structural fire testing with respect to both the level of complexity of the 'fire model' and the level of complexity of the 'structural model' used in testing. This figure has been created following the lead of Buchanan (2001) who has previously presented a similar table to show that researchers must strive to achieve 'consistent crudeness' during testing in terms of how they treat the fire and the structure.

It is obvious in Figure 1 that standard furnace testing falls near the top left corner of the table, where both the 


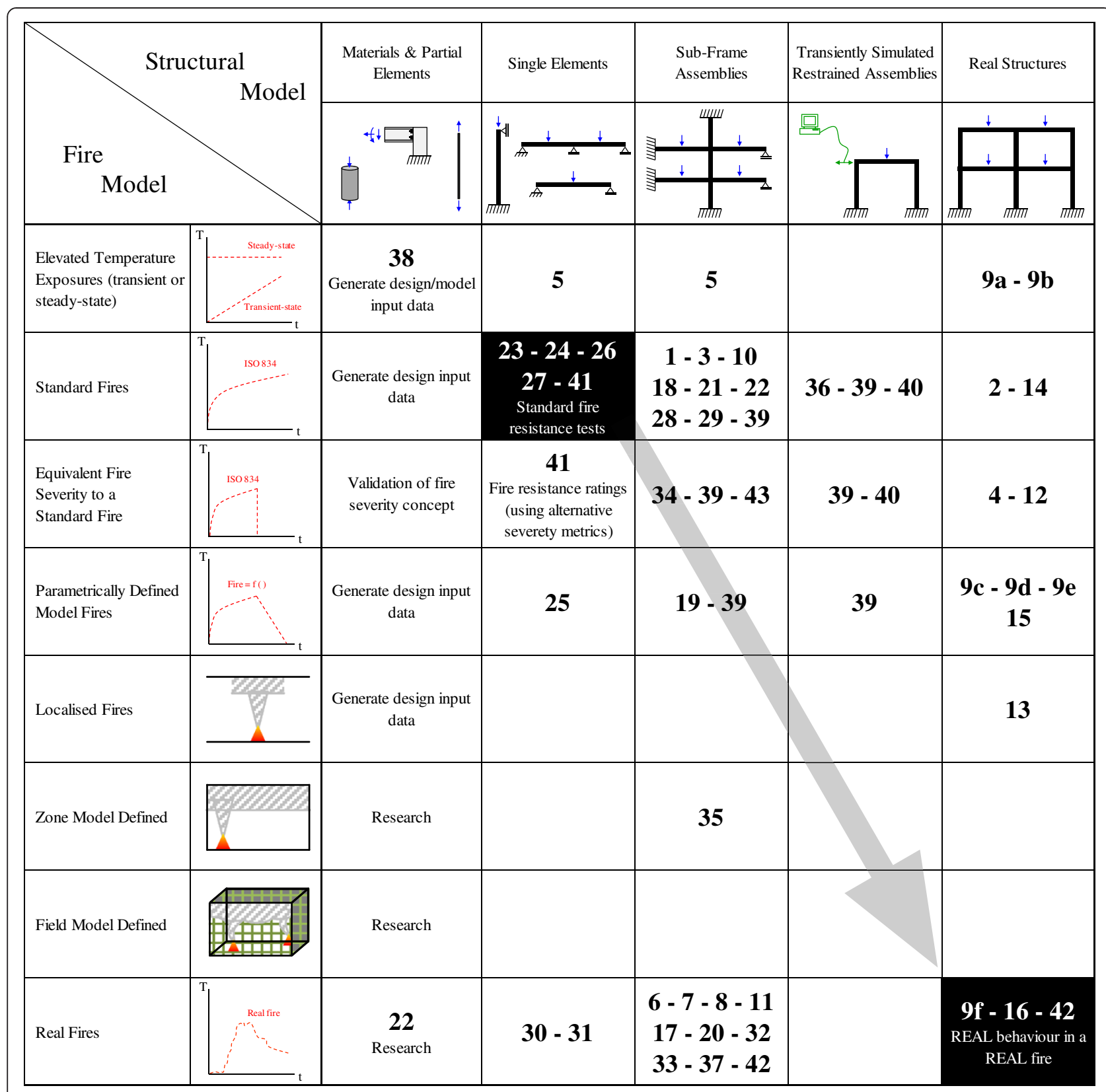

Figure 1 'Crudeness framework' which categorizes possible structural fire testing methodologies with respect to both the level of complexity of the 'fire model' and the level of complexity of the 'structural model' used in testing.

fire and the structure are treated in a very crude fashion. The bottom right corner of the table represents 'reality', and so tests which lie close to the diagonal are most defensible from a consistent crudeness perspective.

Each of the testing programs discussed below has been placed within a cell of this table on the basis of an assessment by the authors of the current paper, allowing readers to gain an intuitive sense of which studies push the community towards the most realistic and defensible outcomes. In Table 1, testing programs discussed are listed in chronological order.

\section{Steel-concrete composite construction}

American iron and steel institute and national building standards test (1982)

The renaissance of large-scale structural fire testing probably started with tests performed by the American Iron and Steel Institute (AISI) and the National Building 
Table 1 Large-scale non-standard structural fire tests listed in chronological order

\begin{tabular}{|c|c|c|c|}
\hline Test* & Year (approx.) & Name of test and/ or research institute & Reference \\
\hline 1 & 1959 & Unbonded post-tensioned beam and slab assembly, USA & Troxell, 1959 \\
\hline 2 & 1982 & AISI and NBS, USA & Jeanes, 1982 \\
\hline 3 & 1983 & Multi-span continous unbonded post-tensioned slabs, Belgium & Van Herberghen and Van Damme, 1983 \\
\hline 4 & 1985 & Stuttgart-Vaihingen University Germany & British Steel, 1999 \\
\hline 5 & 1986 & Steel beams and portal frames with uniform heating, Germany & Rubert and Schaumann, 1986 \\
\hline 6 & 1987 & Steel portal frame with fire load of wooden cribs, BRE, UK & Cooke and Latham, 1987 \\
\hline 7 & 1992 & BHP-William Street, Australia & British Steel, 1999 \\
\hline 8 & 1994 & BHP-Collins Street, Australia & British Steel, 1999 \\
\hline $9 a$ & 1996 & BRE Cardington Steel Building (Test 1), UK & British Steel, 1999 \\
\hline $9 b$ & 1996 & BRE Cardington Steel Building (Test 2), UK & British Steel, 1999 \\
\hline $9 c$ & 1996 & BRE Cardington Steel Building (Test 3), UK & British Steel, 1999 \\
\hline $9 d$ & 1996 & BRE Cardington Steel Building (Test 4), UK & British Steel, 1999 \\
\hline $9 e$ & 1996 & BRE Cardington Steel Building (Test 5), UK & British Steel, 1999 \\
\hline 9f & 1996 & BRE Cardington Steel Building (Test 6), UK & British Steel, 1999 \\
\hline 10 & 1997 & Punching shear test in standard testing furnaces Germany & Kordina, 1997 \\
\hline 11 & 1998 & Car Park Fire Tests, CTICM, France & Vassart and Zhao, 2011 \\
\hline 12 & 1999 & BRE Cardington Timber Frame, UK & Lennon et al., 2000 \\
\hline 13 & 1999 & Tests on steel portal frames with pool fires, UK & Wong et al., 1999 \\
\hline 14 & 1999 & Tests on steel portal frames with furnace with furnace exposure, China & Zhao and Shen, 1999 \\
\hline 15 & 2001 & BRE Cardington Concrete Building, UK & Bailey, 2002 \\
\hline 16 & 2003 & BRE Carington Steel Building (Test 7), UK & Wald et al., 2006 \\
\hline 17 & 2006 & Ostrava Fire Test, Czech Technical University, Czech Republic & Chlouba et al., 2009 \\
\hline 18 & 2007 & Harbin Institute of Technology, China & Dong and Prasad, 2009a \\
\hline 19 & 2007 & BRE Hollow-Core Slab Fire Test, UK & Bailey and Lennon, 2008 \\
\hline 20 & 2008 & Mokrsko Fire Test, Czech Technical University, Czech Republic & Chlouba and Wald, 2009; Wald, 2010; Wald, 2011 \\
\hline 21 & 2008 & FRACOF Fire Test, Metz, France & Vassart and Zhao, 2011 \\
\hline 22 & 2008 & COSSFIRE Fire Test, Metz, France & Vassart and Zhao, 2011 \\
\hline 23 & 2008 & Long span post-tensioned slab tested in a large furnace, UK & Kelly and Purkiss, 2008 \\
\hline 24 & 2008 & Model continuous post-tensioned concrete slab standard fire, China & Li-Tang et al., 2008 \\
\hline 25 & 2008 & Steel frames tested under 'natural' fires, Portugal & Santiago et al., 2008 \\
\hline 26 & 2009 & Two-dimensional steel frames in custom furnace, China & Dong and Prasad, 2009b \\
\hline 27 & 2010 & Continuous post-tensioned concrete slabs in furnace, China & Zheng et al., 2010 \\
\hline 28 & 2010 & Planar portal frames in standard fire exposures, China & Han et al., 2010 \\
\hline 29 & 2010 & Hong Kong Fire Test, Hong Kong Polytechnic University, China & Wong and Ng, 2011 \\
\hline 30 & 2010 & CCAA-CESARE Test, Australia & CCAA, 2010 \\
\hline 31 & 2010 & University of Ulster, UK & Nadjai et al., 2011 \\
\hline 32 & 2011 & Punching shear tests in standard testing furnaces, Belgium & Annerel et al., 2011 \\
\hline 33 & 2011 & TU Munich Fire Tests, Germany & Stadler et al., 2011 \\
\hline 34 & 2011 & TU Vienna Fire Tests, Austria & Ring et al., 2011 \\
\hline 35 & 2011 & University of Edinburgh and IIE Roorkie Test, India & Sharma et al., 2012 \\
\hline 36 & 2011 & NRC, Ottawa, Canada & Mostafaei, 2011 \\
\hline 37 & 2011 & Veseli Fire Test, Czech Technical University, Czech Republic & Wald et al., 2011 \\
\hline 38 & N/A & University of Sheffield's connection testing furnace, UK & Yu et al., 2011 \\
\hline 39 & N/A & CERIB Promethee Facility, France & Robert et al., 2009 \\
\hline
\end{tabular}


Table 1 Large-scale non-standard structural fire tests listed in chronological order (Continued)

\begin{tabular}{llll}
\hline 40 & N/A & BAM Column Test Facility, Germany & Korzen et al., 2010 \\
41 & N/A & CSTB Vulcain Test Facility, France & CSTB, 2011 \\
42 & N/A & NIST NFRL Extension Test Facility, USA & NIST, 2011 \\
43 & Planned? & University of Victoria CESARE Fire Test, Melbourne, Australia & Proe and Thomas, 2010 \\
\hline
\end{tabular}

* Reference Figure 1 .

Standards (NBS) with the objective of assessing the global behavior of steel-concrete composite frame structures and validating an early computer modeling package, called FASBUS II, for structural response to fire (Jeanes 1982). A large-scale non-standard structural fire test was executed on a two-story, four-bay $(9.8 \mathrm{~m} \times 12.2$ $\mathrm{m}$ in plan) composite steel-framed building. The test structure was intended to represent a corner section of a typical mid-rise office building. A fire compartment was built into one corner bay of the structure, and a fire load was supplied by propane burners which 'reproduced' 100 minutes of the ASTM E119 (ASTM 1980) standard fire. Water tanks were used to impose the design live loads during the test.

While few details of the test are available in the literature, the test clearly demonstrated that 'full structure' response to a fire was markedly different to that which would be expected on the basis of furnace testing. It highlighted a number of differences in response between the performance of a real structure and the performance of an isolated structural element, albeit in both cases under a standard fire heating scenario. Most importantly, secondary load paths, structural interactions, membrane actions, and discrete cracking in the concrete slabs, none of which would have been identified by furnace tests, were all identified as playing roles in the structure's response.

\section{Stuttgart-Vaihingen University Fire Test (1985)}

Another early large-scale non-standard fire test was performed at Stuttgart-Vaihingen University, Germany, in 1985 (Anon 1986). Little information on this test is available in the English literature; only a brief description is available in the British Steel (1999) report on the Cardington fire tests (see below).

The Stuttgart-Vaihingen University test was performed on the third floor of a four-storey steel framed office building in which many different forms of steel and concrete composite elements had been used. The building incorporated water filled columns, partially encased columns, concrete filled columns, steel-composite beams, and various types of composite floor systems. The imposed fire load consisted of wooden cribs over about one third of its floor area. The structure was loaded by water-filled barrels.
Despite gas phase temperatures in excess of $1000^{\circ} \mathrm{C}$, the building maintained its structural integrity and experienced maximum beam deflections of only about 60 $\mathrm{mm}$. The building was refurbished after the fire and subsequently occupied as an office and laboratory space. Little other information is available.

\section{William Street Tests (circa 1992)}

In the early 1990s a series of four fire tests was performed by steel company BHP to investigate the structural fire performance of a specific steel-framed office building in Melbourne, Australia. The existing 41 storey building (140 William Street) was undergoing renovation and refurbishment after an extensive asbestos removal program. The test was intended to show that with the installation of a light hazard sprinkler system and a non-fire rated suspended ceiling, that the passive fire protection could be removed from the structural steelwork of the beams and the underside of the steel deck floors (British Steel 1999, Thomas et al. 1992).

A test building was constructed to simulate a typical single storey corner bay of the Willam Street building; i.e. an isolated $12 \mathrm{~m} \times 12 \mathrm{~m}$ bay. The fuel load consisted of typical office furnishings amounting to a fuel load of about $53.5 \mathrm{~kg} / \mathrm{m}^{2}$. Gravity loads were applied using water tanks.

The first two tests were concerned primarily with the effectiveness of the proposed sprinkler system, and as such the fires were not significant for the structure. The third test examined the structural and thermal performance of the composite slab. In this test the beams had 'partial fire protection' and the entire floor assembly was protected (to unknown extent) by a suspended ceiling system which 'remained largely in place' during the fire exposure. Peak gas phase temperatures were about $1254^{\circ} \mathrm{C}$, but the (protected?) composite slab supported the imposed service load. The fourth test used unprotected steel beams and composite slab, although still with a suspended ceiling, and had a peak gas phase temperature of $1228^{\circ} \mathrm{C}$. The maximum beam temperatures in this test were $632^{\circ} \mathrm{C}$, and the maximum beam deflection was $120 \mathrm{~mm}$ (with no 'obvious signs' of impending collapse). 'Most' of the beam deflection was recovered on cooling.

Taken together, the four William Street tests were used to demonstrate, with minimal analysis, that the light hazard sprinkler system was adequate to prevent deformation and collapse and that fire protection was not required on 
the beams or underside of the composite slab in this building (British Steel 1999).

\section{Collins Street Test (circa 1994)}

Shortly after the William Street tests, BHP performed a fire test in a steel-framed test building which was intended to simulate a section of a proposed multistorey building in Collins Street, Melbourne (British Steel 1999, Proe and Bennetts 1994). The test was concerned primarily with the fire dynamics and measured temperatures in the steel, and is not particularly enlightening in terms of structural response.

An $8.4 \mathrm{~m} \times 3.6 \mathrm{~m}$ compartment was loaded with $44-$ $49 \mathrm{~kg} / \mathrm{m}^{2}$ of 'typical' office furniture. Peak gas phase temperatures of $1163^{\circ} \mathrm{C}$ were recorded, although the maximum steel beam temperature was only $470^{\circ} \mathrm{C}$. It is noteworthy that this test also included a suspended ceiling, which considerably reduced the temperatures measured in the structural elements, and that the structure had no imposed loading other than self-weight.

On the basis of this test, BHP successfully argued that no fire protection was required to the beams and the external steel columns. It has recently been noted (Vassart and Zhao 2011) that the Williams and Collins Street Fire tests have enabled - in conjunction with risk assessments and the use of sprinkler systems with a 'sufficient' level of reliability - the use of unprotected beams in six multi-storey office buildings between 12 and 41 storeys in Australia (up to 1999). However, exactly what level of 'reliability' is required of the sprinkler systems is not stated. The reliance of these conclusions on the performance of the non fire rated suspended ceilings is also highly problematic in practice (British Steel 1999) and thus difficult to justify.

\section{BRE Cardington Steel Building Tests (1996)}

In 1996 a number of large-scale non-standard structural fire tests were performed in an eight storey composite steel-framed test building constructed at the Cardington site of the UK Building Research Establishment (BRE). In total, seven fire tests on this structure are reported in the literature, with the definitive reference for the first six of these being a research report by British Steel (1999). The building was $21 \mathrm{~m} \times 45 \mathrm{~m}$ and three bays by five bays in plan, and had a total height of $33 \mathrm{~m}$. All beams were designed as simply supported acting compositely with a $130 \mathrm{~mm}$ thick concrete slab on steel decking. Beam-to-beam connections were made using fin-plate connections and beam-to-column connections using flexible end plates. Sandbags were used to simulate gravity loads for a typical office occupancy. A plan view of the test structure is given in Figure 2; this also shows the approximate locations and compartment sizes for the various fire tests performed.
Test 1 studied the behavior of a single $9 \mathrm{~m}$ long internal, restrained secondary beam (along with the surrounding floor slab) in an edge bay of the building. The beam was heated inside a custom built $8 \mathrm{~m} \times 3 \mathrm{~m}$ gasfired furnace. The connections were kept outside the furnace and were thus not directly heated. The beam was heated relatively slowly (at between 3 and $10^{\circ} \mathrm{C}$ per minute) to a peak temperature close to $900^{\circ} \mathrm{C}$, while the temperatures and deflections of the structure were monitored. This test was intended to examine the effects of restraint on a heated beam from the surrounding cooler structure. The peak steel temperature was $887^{\circ} \mathrm{C}$ measured on the bottom flange, while the peak gas temperature was $913^{\circ} \mathrm{C}$. The most notable observations were that:

- the 'runaway' displacement which is typically observed in standard furnace tests of simply supported steel beams was not observed, despite maximum temperatures of $875^{\circ} \mathrm{C}$ being observed in the beam's bottom flange;

- local buckling (and hinging) occurred at both ends of the beam just inside the furnace where the beam transitioned from cool to hot; and

- tensile failure of the beam-to-column end-plate connections occurred during the cooling phase of the fire due to contraction of the steel on cooling.

Test 2 was used to study the behavior of a single storey plane frame across the entire profile of the building. This included four columns and three primary beams (see Figure 2). The test was again performed inside a custom built gas fired furnace, in this case $21 \mathrm{~m} \times$ $2.5 \mathrm{~m}$ in plan. The top $800 \mathrm{~mm}$ of the columns and all beams and the underside of the composite slab were left unprotected, including the beam-column connections. The heating regime was similar to Test 1 . The peak steel temperature was $800^{\circ} \mathrm{C}$ while the peak gas temperature was $820^{\circ} \mathrm{C}$. Notable observations were that:

- the exposed (top) portions of the columns buckled locally and squashed by about $180 \mathrm{~mm}$ when their temperatures reached $670^{\circ} \mathrm{C}$;

- this column deformation caused a permanent deformation of $180 \mathrm{~mm}$ over all floors above the fire compartment (indicating that fire protection of columns is of paramount importance); and

- many bolts in the fin-plate connections between the primary and secondary beams (which had been heated over a length of only $1 \mathrm{~m}$ adjacent to the primary beams) sheared due to thermal contraction of the secondary beams on cooling.

Test 3 was concerned with the behavior of the complete floor system, with a particular interest in membrane 


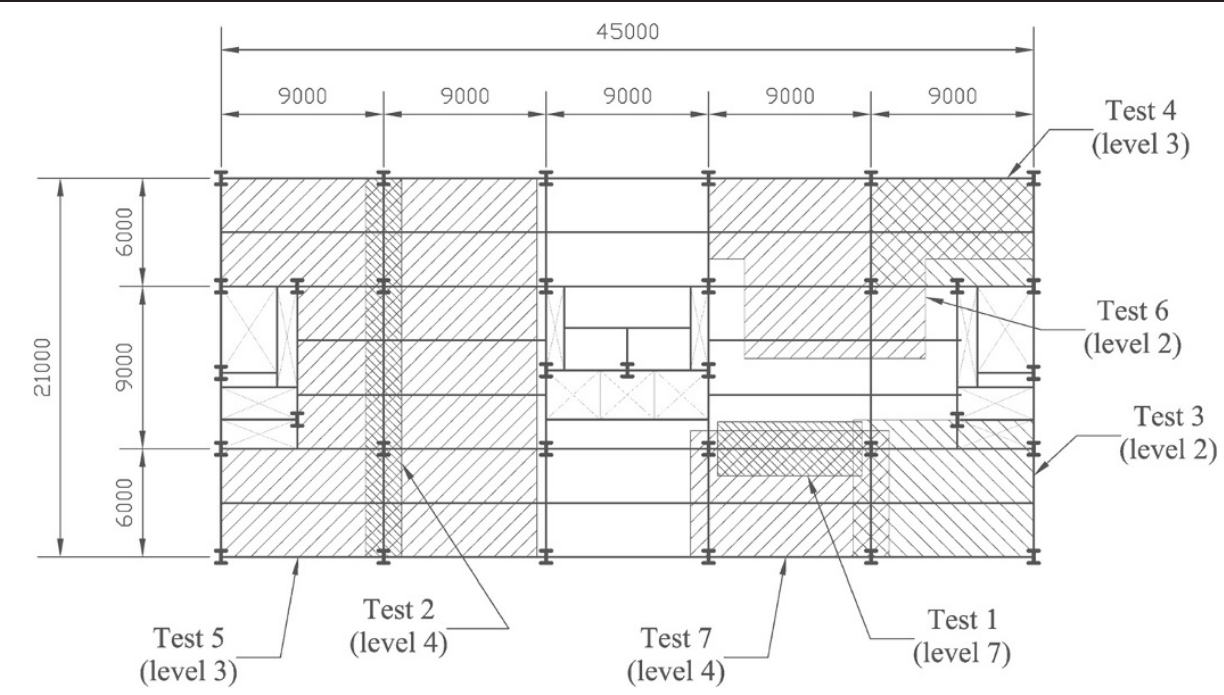

Figure 2 Plan view of the Cardington Test Frame and locations of the seven fire tests performed in this structure (reproduced after Vassart and Zhao (2011)).

actions and alternative load paths. The test was performed on the $1^{\text {st }}$ floor of the building in a $9 \mathrm{~m} \times 6 \mathrm{~m}$ cornercompartment (see Figure 2), using a fire load of $45 \mathrm{~kg} / \mathrm{m}^{2}$ of timber cribs. This resulted in a peak measured gas phase temperature of $1071^{\circ} \mathrm{C}$. All columns, beam-to-column connections, and edge beams were protected. The key observations were that:

- a maximum vertical displacement of less than span/20 occurred at the centre of the secondary beam at a peak temperature of $954^{\circ} \mathrm{C}$ (less than half of this deflection was recovered on cooling and the structure was left with considerable irreversible deformations);

- the structure showed no signs of collapse; and

- buckling occurred near some of the beam-to -column connections in both the web and the lower flange, although in this test there was no shear failure of the bolted connections.

Test 4 was also concerned with the behavior of the complete floor system, but also studied issues in compartmentation using steel stud partition walls. This test was performed in a $54 \mathrm{~m}^{2}$ corner compartment of the second floor of the building (refer to Figure 2) using timber cribs with a fire load of $40 \mathrm{~kg} / \mathrm{m}^{2}$. All columns and connections were fire protected. The maximum recorded gas phase temperature was $1051^{\circ} \mathrm{C}$, whereas the peak steel temperature was $903^{\circ} \mathrm{C}$ measured at the bottom flange of the central beam. Conclusions were that:

- a large slab displacement of $269 \mathrm{~mm}$ occurred at the centre of the compartment, which remained 160 $\mathrm{mm}$ after cooling;
- interactions between the fire exposed floor framing and the non fire exposed wind bracing above the test compartment were observed, reducing beam displacements and demonstrating the potential importance of capturing full-structure interactions during fire tests; and

- No local buckling was observed and the connections showed no signs of fracture on cooling.

Test 5 was a large compartment test intended to study the global behavior of the structure in a $21 \mathrm{~m} \times 18 \mathrm{~m}$, side-compartment between the second and third floors of the building (Figure 2). The compartment area was 340 $\mathrm{m}^{2}$ and was uniformly fire loaded with wooden cribs at 40 $\mathrm{kg} / \mathrm{m}^{2}$. All of the steel beams, including the edge beams, were left unprotected; columns and connections were protected. The maximum recorded gas phase temperature was only $746^{\circ} \mathrm{C}$, and the maximum steel temperature was $691^{\circ} \mathrm{C}$ at the centre of the compartment. Despite these relatively low temperatures a number of interesting observations were made, including that:

- a maximum slab displacement of $557 \mathrm{~mm}$ was recorded which only recovered to $481 \mathrm{~mm}$ on cooling;

- local buckling was observed near the beam-to-beam connections; and

- several of the end-plate connections fractured down one side on cooling, and in one case the web detached from the end-plate resulting in a total loss of shear capacity, which caused large cracks in the composite slab above the connection but did not lead to collapse. 
Test 6 was a demonstration test using a fire load of real office furniture, again to study the global behavior of the structure in a large $(18 \mathrm{~m} \times 9 \mathrm{~m})$, open plan cornercompartment of the building. In addition to office furniture, wood and plastic cribs were added to give a fire load of $45 \mathrm{~kg} / \mathrm{m}^{2}$. Primary and secondary beams, including beam-to-beam connections, were exposed to the fire, while columns and beam-to-column connections were protected. A maximum gas phase temperature of $1213^{\circ} \mathrm{C}$ was recorded, with maximum temperatures of the unprotected steel in the range of $1150^{\circ} \mathrm{C}$. The main observations were that:

- maximum vertical deflections of $640 \mathrm{~mm}$ were observed and recovered only to $540 \mathrm{~mm}$ on cooling;

- the structure showed no signs of impending collapse, although the wind bracing in the floors above the test compartment probably offered alternative load paths (and the structure was able to rest on the blockwork walls forming the fire compartment at least one location during the test); and

- the composite steel-concrete floor slab showed considerable cracking around one of the columns during cooling; investigation revealed that the steel mesh reinforcement in the concrete slab had not been lapped correctly but simply butted together (this is clearly undesirable).

Test 7 is reported in detail by Wald et al. (2006) and studied the global behavior of the structure in an $11 \mathrm{~m} \times 7$ $\mathrm{m}$, side-compartment of the building. This test was concerned primarily with issues around tensile membrane action and the robustness of steel connections during fire. Two primary beams (unprotected), two columns (protected), and three secondary beams (unprotected) were exposed to fire (Figure 2) with a fire load consisting of $40 \mathrm{~kg} / \mathrm{m}^{2}$ of wood cribs. The maximum recorded gas phase temperature was $1108^{\circ} \mathrm{C}$, with a maximum steel temperature of $1088^{\circ} \mathrm{C}$. Key observations were that:

- no collapse was observed despite maximum deflections up to $1200 \mathrm{~mm}$ which recovered by about $925 \mathrm{~mm}$ on cooling;

- buckling of the beams occurred adjacent to the joints during the heating phase resulting from restraint to thermal expansion provided by the surrounding structure; and

- as in Test 6 , cracking of the concrete slab occurred at the column heads due to non-lapped steel mesh in the concrete slab.

Taken together, these seven tests demonstrated many important aspects of the full-structure response of composite steel-framed buildings during fire. In particular, they shed light on the secondary load carrying mechanisms which can be activated during fire to prevent collapse, the potential importance of restraint to thermal expansion on heating (and thermal contraction on cooling) on localized buckling and/or connection failures, and the fact that full-structure response in fire is markedly different than that observed in standard fire resistance tests performed in furnaces. In the case of regular grid plan composite steel-framed buildings such as the one tested at Cardington, the fire resistance appears to be far greater than is normally assumed on the basis of furnace tests. This conclusion has been used to great advantage in recent years by the Steel Construction Industry (in particular in Europe) to justify removal of passive fire protection from secondary steel beams and steel decking in composite framed steel buildings, with considerable aesthetic, economic, sustainability, and constructability benefits.

\section{Car Park Fire Tests (1998-2001)}

A series of fire tests was conducted by the European Coal and Steel Council on an open-sided composite steel-framed car park structure circa 2002 (see Joyeux et al. 2001). The objective of these tests was to show 'satisfactory' structural fire performance without requiring any fire protection to the structure. A single story structure $16 \mathrm{~m} \times 32 \mathrm{~m}$ in plan, with a height of $3 \mathrm{~m}$, was constructed from unprotected steel columns, steelconcrete composite beams, and a steel-concrete composite slab with a depth of $120 \mathrm{~mm}$. The structure was loaded with real cars, and the fuel (in the most severe of the three tests) consisted of three real cars burning simultaneously and exposing a 'significant area' of the floor to the flames of the fire in a localised manner (Vassart and Zhao 2011). This resulted in the steel beams above the fire being heated to more than $700^{\circ} \mathrm{C}$.

No collapse of the structure was observed during the tests, and maximum vertical deflections of only $150 \mathrm{~mm}$ were observed in the composite deck. These tests again highlighted the positive influence of full structure response (particularly membrane actions) for composite steel structures during fire. These tests have subsequently been used to develop 3D modeling tools and design tables for the structural fire design of composite car parks which have been used in a number of fire safety engineering projects in France (Vassart and Zhao 2011).

\section{Ostrava Fire Tests (2006)}

Chlouba et al. (2009) briefly describe two fire tests on an unprotected steel floor carried out in a three-storey office building in Ostrava, Czech Republic, in 2003. The fire compartment was $3.8 \mathrm{~m} \times 6.0 \mathrm{~m}$ in plan with a height of $2.8 \mathrm{~m}$. Mechanical load was applied and wooden cribs were used to give a fire load density of 
$1039 \mathrm{MJ} / \mathrm{m}^{2}$. The first test used a localised fire to measure the temperature of a steel column and beams close to the centre of the localised fire. The second test was a compartment test and was designed to obtain the gas temperatures in the fire compartment and the temperatures of the steel beams. However, the reported results did not address structural performance.

\section{Harbin Institute of Technology Tests (circa 2007 \& 2010)}

Dong and Prasad (2009a) present the details of a largescale experimental study to 'understand the performance of structural frames under fire loading' and to 'to serve as a database with which to check and validate numerical models'. To do this, they constructed a planar twostorey, two-bay composite steel sway portal frame with fixed column base connections and subjected it to thermal loading by placing it inside a custom made testing furnace under sustained gravity loading.

Each bay of the frame spanned $3.6 \mathrm{~m}$ and each storey was $2.8 \mathrm{~m}$ in height. The frame consisted of three vertical steel columns, linked together by four steel-concrete composite beams with composite action assured using shear studs. The depth of the reinforced concrete slab was $100 \mathrm{~mm}$ and the width of slab was $1000 \mathrm{~mm}$. Beam-to-column connections were bolted end-plate connections which were designed to transfer both moments and shear forces. Beams were unprotected, but columns and beam-to-column connections were insulated. A unique testing furnace was designed to accommodate the frame while applying vertical loading with hydraulic jacks and allowing the large displacements expected during testing. Full details of the rather unusual test facility are given by Dong and Prasad (2009a).

Three individual tests were conducted; these differed in the number of 'compartments' that were heated by the furnace and in the relative location of the heated compartments. Tests included both heating and cooling phases using non-standard fires with peak gas phase temperatures in the range of $900^{\circ} \mathrm{C}$ occurring after between 60 and 115 minutes. Keeping in mind that this (two-dimensional) frame structure cannot be considered representative of a real (three-dimensional) structure, the key conclusions resulting from this study were that (Dong and Prasad 2009a):

- none of the columns in any of the tests displayed local buckling or plastic hinge formation;

- structural failure was observed in the beam-to -column connections, the composite beam and the concrete slab. This was caused by contraction of the steel beams on cooling resulting in tensile connection failure (note that this occurred in tests when the beam was exposed to the fire but the connections were insulated, thus minimizing the heating of the connection.);
- local buckling of the steel beams near the end of their heated spans was observed (again this has been seen in prior tests by others);

- tensile cracking of the concrete slabs was observed near the span ends (as expected); and

- unsurprisingly, the deformation process and time to failure of the structure depended on the number and relative location of compartments that were heated (it should be noted that it is not clear how the authors define 'failure').

\section{Mokrsko Fire Test (2008)}

A large-scale fire experiment was conducted in a purpose-built test structure by the Czech Technical University during September 2008. The test was performed in Mokrsko, Czech Republic, and was designed to study the overall behavior of a test structure as well as its individual elements (Wald 2010, Chlouba and Wald 2009). A problem in interpreting the results of this test is that six different wall structures and three types of flooring systems were all tested simultaneously, so the impacts of localized failures of individual components are difficult to separate from the global response of the structure.

Wald (2011) states that the main objective this test was to observe the temperatures of header plate connections which were partially encased in the concrete slab, the behavior of castellated composite beams with sinusoidal openings (called 'Angelina' beams), and the behavior of unusual beams with thin corrugated steel webs. The test structure was intended to represent one floor of an office building $12 \mathrm{~m} \times 18 \mathrm{~m}$ in plan with a height of $4 \mathrm{~m}$. Wooden cribs totalling $35.5 \mathrm{~kg} / \mathrm{m}^{2}$ were used for the fire load and plastic bags filled by 'road-metal' were used to apply gravity loads representing a typical office occupancy.

Some interesting behaviors were observed during this test, because the structure was a mix of different components and systems it cannot be considered representative of any real structure, a number of interesting localized failure modes were observed. The interested reader is encouraged to consult (Wald 2010) for a full description of the test and its outcomes.

\section{FRACOF Fire Test (circa 2008)}

Vassart and Zhao (2011) present the results of two fire tests performed as part of an EU Commission-funded Leonardo Da Vinci project on "Fire Resistance Assessment of Partially Protected Composite Floors (FRACOF)". The first of these tests was called the FRACOF test and was intended to investigate the applicability of the Cardington test conclusions for standard fires of longer duration (up to 120 minutes as opposed to 90 minutes), for different construction details, and for the effect of higher gravity loading applied during the fire. To investigate these issues, a single bay (intended to 
represent a corner bay of a larger structure) of a composite steel framed building was constructed. The building was one storey high and $8.74 \mathrm{~m} \times 6.66 \mathrm{~m}$ in plan, with columns at the four corners, two primary beams spanning $6.6 \mathrm{~m}$ between the columns and four secondary beams spanning $8.74 \mathrm{~m}$ between primary beams. The $155 \mathrm{~mm}$ deep composite slab spanned $2.2 \mathrm{~m}$ between secondary beams. All four columns and the perimeter beams were fire protected, whereas the internal secondary beams and composite slab were left unprotected. Care was taken around the perimeter of the structure to ensure good connection between the composite slab and the perimeter beams.

Loading was applied to the structure using sand bags equally distributed over the floor plate, and the entire bay was exposed to the ISO 834 (ISO 1999) standard fire for 120 minutes using a furnace (with response monitored also during the cooling phase). Full details of the results are not reported here, but the main observations were that (Vassart and Zhao 2011):

- no collapse was observed for more than 120 minutes of fire exposure despite tensile failure of steel mesh reinforcement in the concrete slab;

- failure of the integrity and insulation criteria were observed due to the formation of a central crack across the slab resulting from premature failure of the reinforcing steel mesh in the composite slab (however what is meant by 'premature' is not clear);

- 'proper' overlapping of reinforcing steel mesh in the composite slab is essential to activate tensile membrane action and to ensure continuity of load transfer, particularly around columns;

- concrete cracking at the edge of the floor was limited and had no influence on the integrity and insulation performance of the floor (although it should be noted that the rotational restraint of the floor slab at the perimeter was probably marginal as continuity of the floor plate was not assured); and

- the floor behaved 'satisfactorily' during the heating and cooling phases of the fire, as did all protected joints between steel members.

\section{COSSFIRE Full Scale Fire Test (circa 2008)}

The second test described by Vassart and Zhao (2011) was called the COSSFIRE test and was similar to the FRACOF test in scale but with minor modifications which allowed investigation of six different slab edge connections during a single standard fire exposure. Details of the test structure are omitted here, but it was essentially a composite steel framed structure of the same size as the FRACOF structure, with protected perimeter beams and columns but unprotected secondary beams and a $135 \mathrm{~mm}$ deep steelconcrete composite slab. It is noteworthy that this test structure incorporated an unprotected secondary edge beam. The structure was loaded using sandbags and subjected to 120 minutes of the ISO 834 (ISO 1999) standard fire with response being monitored during the cooling phase. It was observed that:

- the deflection of the floor was more than $500 \mathrm{~mm}$ after 120 minutes, although it behaved 'very well' and there was no sign of failure 'in the central part' of the floor;

- the test was stopped due to large deflection and flexural failure of the unprotected secondary edge beam, however this failure did not lead to global collapse due to load redistribution from membrane effects;

- local buckling was observed in unprotected secondary beam connections, near to the joints and in the lower flange and web, although all connections performed well during both heating and cooling phases;

- no failure of the edge connections between concrete slab and steel members (via shear studs) was observed;

- cracking of concrete around columns, could have a negative impact on integrity criteria;

- no significant cracking of the concrete slab was observed in the central part of the floor, meaning that the reinforcing steel mesh behaved in membrane action up to $500^{\circ} \mathrm{C}$; and

- an edge detail of lapping steel reinforcing mesh in the concrete slab over shear studs on the edge beams was effective and should be applied in practice for this type of structure.

\section{University of Ulster Fire Test (2010)}

Nadjai et al. (2011) present the results of a full-scale non-standard structural fire test performed by the University of Ulster (and collaborators) in Northern Ireland in February 2010. The fire test was on an unrestrained composite floor system supported on long-span cellular steel beams, and was apparently aimed at studying the development of tensile membrane action when the unprotected steel beams in the central part of a structural bay are cellular, rather than solid web, beams.

The structure was single bay, $15 \mathrm{~m} \times 9 \mathrm{~m}$ in plan, and with a height of $3 \mathrm{~m}$. The surrounding infill walls were not fixed to the composite floor at the top to allow vertical movement of the floor. All of the columns and perimeter beams were fire protected. The composite deck slab had a total depth of $120 \mathrm{~mm}$ and was fixed to edge beams by lapping the steel reinforcing mesh over shear studs welded to the perimeter beams (as in the case of the COSSFIRE test). A natural fire was imposed using wooden cribs at a load of $587 \mathrm{MJ} / \mathrm{m}^{2}$, resulting in a gas 
phase temperature $500 \mathrm{~mm}$ below the ceiling at $75 \mathrm{mi}$ nutes which peaked at $1055^{\circ} \mathrm{C}$.

The main conclusions from this study demonstrated that using cellular secondary beams to support a composite slab does not jeopardise the tensile membrane action that develops in such a slab in a fire situation. Maximum steel reinforcing mesh temperatures in the slab were less than $375^{\circ} \mathrm{C}$, suggesting less than $5 \%$ strength loss. As an aside, it is noteworthy that despite using various tools (e.g. the Ozone program (Cadorin et al. 2001) and the predicted parametric fire curve specified in BS EN1991-1-2 (CEN 2002)) to predict anticipated compartment temperatures, the actual fire was more severe than predicted.

\section{TU Munich Fire Tests (2010)}

Stadler et al. (2011) reported large-scale non-standard tests on a steel-concrete composite slab intended to enable structural fire designers in Germany to take account of membrane action for SFE design of composite beam-slab systems. The main objective of the project was to understand the behavior of intermediate beams between two composite slab panels. To do this, two fire tests were performed on composite slab panels $5 \mathrm{~m} \times 12.5 \mathrm{~m}$ in plan with unprotected secondary beams in different directions and configurations. Rather unusually, all edge beams were protected with an intumescent coating. The orientation of the secondary beams, the flooring system and the intumescent coating system were all varied. The first test used a 'lattice girder precast concrete slab' while the second used a profiled steel sheeting composite slab. The structure was exposed to a natural fire using wooden cribs to obtain gas temperatures which exceeded $900^{\circ} \mathrm{C}$ during both tests. Very little other information is currently available on the test results.

\section{Veseli Fire Tests (2011)}

Wald et al. (2011) have presented results from two fire tests performed by the Czech Technical University in Veseli, Czech Republic, during 2011 to investigate the 'design of joints to composite columns for improved fire robustness'. The tests were performed in a rather unusual purpose-built test structure designed to represent a section of an office building. The two storey building was $10.4 \mathrm{~m} \times 13.4 \mathrm{~m}$ in plan with a height of $9 \mathrm{~m}$, and incorporated a number of innovative construction techniques, including steel fiber reinforced concrete slabs, concretefilled structural hollow section columns, several different external cladding systems, partial fire protection in various parts of the structure, and a number of different beam to column connection details. A natural fire exposure was imposed, consisting of non-uniformly placed timber cribs with a fuel load of $174 \mathrm{MJ} / \mathrm{m}^{2}$ in the central region of the structure. The applicability of the results of these tests to real structures is not clear since the many factors investigated confound the results of individual features. In any case, detailed experimental observations and conclusions from these tests are not yet available.

\section{University of Victoria CESARE Fire Test (Planned?)}

Proe and Thomas (2010) present plans for a large-scale fire test on a steel-frame composite concrete floor system suspended $3 \mathrm{~m}$ above the floor of a test building in Melbourne, Australia 'in late in 2010'. The authors stated that 'the test will facilitate investigation of the fire behavior of one storey of a typical office building structure as used in Australia for a particular configuration of unprotected steel beams'. Essentially the test is meant to study membrane action in composite steel framed buildings in a manner similar to the Cardington, FRACOF, and COSSFIRE tests described previously, however using a natural pool fire in this case. Apparently the test structure had plan dimensions of $20 \mathrm{~m} \times 16 \mathrm{~m}$, incorporating nine columns and divided into two bays in each orthogonal direction. The test was designed to shed light on (Proe and Thomas 2010):

- the ability of protected beams to support load being shed from unprotected beams;

- the effect of beam deflection at the slab perimeter on tensile membrane action;

- the effect of reinforcement ductility and strain localisation on slab failure and deflection; and

- the effect of perimeter horizontal displacement and forces on column capacity.

However, on the basis of information available in the literature it is not clear exactly how these issues were addressed by this specific test (in comparison to previous tests on steel-concrete composite slabs) and no publications appear to be available which describes the test outcome. It is therefore not clear if this test has actually been (or will be) conducted.

\section{Fire tests on portal frames and Sub-frame assemblies}

A number of medium and large-scale non-standard fire tests on steel or steel-concrete composite portal frame structures are available in the literature. These are not directly relevant to the current review since they fail to simulate most of the requisite interactions that might play roles in real structures. However, it is instructive to be aware of the work that has been performed in this area.

Rubert and Schaumann (1986) present a series of tests on 1:4 to $1: 6$ scale steel beam and portal frame structures heated under non-standard exposures using a series of electrical resistance heaters. Structures tested included a simple elbow frame, a portal, and a double portal. The results were used to develop a basic method 
for assessment of the fire resistance steel framed assemblies under bending stress.

Cooke and Latham (1987) performed a single test on a full-scale loaded steel portal frame subjected to fire from a compartment containing wooden cribs (which reached a maximum temperature of only $830^{\circ} \mathrm{C}$ ). This test demonstrated the deflection behaviour of the portal in a natural fire.

Zhao and Shen (1999) experimentally studied the deformation behavior of unprotected two-dimensional, singlestorey, single span steel portal frames exposed to fire. Three tests were performed on steel frames with welded beam-to -column moment connections under different load levels and heating regimes within a custom built gas furnace. Loads were applied only to the column heads, with no applied loads on the top beams of the portal frames.

Wong et al. (1999) performed an experimental study, apparently the only one of its kind, investigating the fire performance of steel portal frame buildings. These tests involved a scaled portal frame building constructed from four portal frames with a span of $6 \mathrm{~m}$ at $1.5 \mathrm{~m}$ centres and with a rafter pitch of $15^{\circ}$. The building was clad with profiled steel sheeting. The base connection condition of the columns was varied (pinned or fixed) amongst three separate tests. Pool fires were used to expose single portals to localized heating, with the columns remaining relatively cool, and the response and failure modes of the structure were observed.

Santiago et al. (2008) present details of a unique testing facility and a series of tests on six steel 'sub-frames' under a 'natural fire' at the University of Coimbra, Portugal, using a custom designed array of gas burners. These tests were intended to provide insight into the influence of various connection types on the behavior of steel substructures in fire. The test structures consisted of two thermally insulated columns and an unprotected steel beam with a $5.70 \mathrm{~m}$ span supporting a lightweight composite concrete slab. Pinned supports were imposed at the top and bottom of the columns. Six tests were performed, varying the beam-to-column connection configuration. These tests demonstrated the already well-known appearance of large tensile forces and reversal of bending moments during the cooling phase of a fire, as well as the fact that these forces may result in failure of the joint.

In addition to the work discussed previously on twostorey, two-bay composite steel portal frames, Dong and Prasad (2009b) have also presented result from furnace tests on two full-scale composite steel frames with a height of $2.8 \mathrm{~m}$ and a span of $3.6 \mathrm{~m}$. In one frame both the beam-to-column connections and the columns themselves were protected, while in the other test only the beam-to-column connections were protected. The frames were subjected to both heating and cooling phases using a specially designed furnace.
Han et al. (2010) have recently presented results from a testing program on six planar portal frame structures with a span of $2.4 \mathrm{~m}$ and a height of $1.46 \mathrm{~m}$ in which the columns consisted of concrete-filled steel hollow structural sections and the beams consisted of reinforced concrete T-sections. These tests were intended to reproduce multi-storey composite construction systems used in China. Test parameters included the shape of the columns (circular or square), the level of axial load in the columns, the load level in the beams, and the beamcolumn stiffness ratio. Only the beams were directly heated during these tests, following the ISO 834 standard fire. While omitting the details of the study and its conclusions, the test showed - rather importantly - that two failure modes were observed: column failure, or beam failure. The fire resistances of the frame were generally lower than those of individual concrete-filled columns tested in isolation but higher than those of isolated reinforced concrete beams. This is a clear indication that in some situations the performance of a structural element in a real building may be not as good as its performance would be in a furnace test; it thus contradicts the fundamental assumption which is widely used to justify furnace testing of isolated structural elements as a credible worst case scenario for comparison.

\section{Testing on steel connections in fire}

In addition to the large-scale non-standard fire tests presented above, a number of testing programs have been undertaken in the past two decades to investigate the performance of connections in steel structures subject to both standard and non-standard heating scenarios. Full details of these are not included here, but the interested reader could refer to Yu et al. $(2009,2011)$ for information on fire testing of steel bolted connections, Ding and Wang (2007) for information on fire testing of connections between steel beams and concrete-filled hollow structural sections, Chung et al. (2010) for tests on steel beam-to-column moment resisting connections, and Yuan et al. (2011) for information on fire testing of connections involving steelconcrete composite beams, including the influence of the concrete deck slab. The important conclusion from this body of work is simply that, as already noted, the performance of structural connections in fire is of fundamental importance to the response of real structures in real fires, and that the relevant failure modes are impossible to observe or predict using standard furnace testing of isolated structural elements.

\section{Reinforced and prestressed concrete}

Comparatively fewer large-scale, non-standard structural fire tests have been performed on reinforced or prestressed concrete structures; mostly because in the absence of explosive cover spalling there is a prevailing 
view that concrete structural elements tend to perform very well in standard furnace tests when compared against unprotected steel elements. Hence, there the concrete industry appears to see relatively little economic benefit arising from support of detailed and costly testing programs to investigate and/or demonstrate the possible benefits of rationally accounting for full structure interactions and alternative load carrying mechanisms (such as membrane action) in reinforced or prestressed concrete structures during fire. Conversely, the steel construction industry has aggressively supported large-scale non-standard structural fire testing largely because of the obvious and considerable economic benefits (and hence competitive edge) that such testing often enables. Nevertheless, a small amount of relevant testing on concrete structures is available in the literature and is described in the following sections. In general the available testing of concrete structures shows that their behaviour in fire is considerably more complicated than would be assumed on the basis of the available prescriptive guidance; this may present both possible benefits and possible risks for concrete structures in fire.

\section{'Non-Standard' testing in furnaces}

Despite the fact that concrete structural elements tend to perform well in isolation during standard furnace tests, it is worth noting that the concrete industry originally led the structural fire resistance community in performing what would now be considered as 'unusual' non-standard furnace tests on concrete structural 'assemblies' rather than focusing on standardized tests. For instance, early testing on two-way post-tensioned concrete slabs and beam-slab assemblies performed in the United States during the 1950s used combinations of beams and slabs to study the two-dimensional response of these types of structures (Troxell 1959). A wealth of furnace test data are available from these early tests, however the focus in the current paper is on more recent efforts so these 'historical' tests are not discussed in detail.

In recent years several authors have presented the results of fire tests on concrete elements or assemblies using custom made or modified standard furnaces to study specific structural response issues or specific types of concrete structures which cannot be easily investigated using a standard 'component' approach. Notable examples include:

- Van Herberghen and Van Damme (1983), who used a modified standard floor furnace to study the fire resistance of post-tensioned continuous but unrestrained flat floor slabs with unbonded prestressing tendons in standard fire conditions;

- Kordina (1997), who used a modified floor furnace to investigate the punching shear behavior of reinforced concrete flat slabs in standard fire conditions;

- Kelly and Purkiss (2008), who used an oversized floor furnace to study the fire resistance of simplysupported, partly-restrained, long-span posttensioned concrete slabs under standard fire exposure;

- Li-Tang et al. (2008), who studied the structural fire behavior of model-scale, three-span continuous unbonded post-tensioned concrete slab strips in a custom built furnace subject to a standard fire;

- Zheng et al. (2010), who performed a series of standard fire tests on two-span, continuous posttensioned concrete slabs in a furnace with a central support built inside the heating chamber; and

- Annerel et al. (2011), who used a modified standard floor furnace to perform punching shear tests on concrete slabs subjected to a standard fire.

Many other examples are available in the literature, but these are peripheral to the current paper, which is concerned predominantly with real fire exposures which include a cooling phase.

\section{Cardington Concrete Building Test (2001)}

To the knowledge of the authors, only a single largescale natural fire test of a 'real' multi-storey concrete building has ever been performed. Bailey (2002) presents the results of a natural fire test on a full-scale, sevenstorey cast in-place concrete building performed at BRE's Cardington test site. The building was constructed as a demonstration building to develop best practice guidance for modern concrete construction technologies, and it therefore incorporated several different concrete mixes and construction techniques. It was three bays by four bays and $22.5 \mathrm{~m} \times 30 \mathrm{~m}$ in plan. It had two cores which incorporated cross bracing for lateral load support. The concrete slab was $250 \mathrm{~mm}$ thick and the columns were either $400 \mathrm{~mm}$ square (internal columns) or $400 \mathrm{~mm} \times 250 \mathrm{~mm}$ (perimeter columns). A number of different reinforcing layouts were used throughout the building, however the reinforcement in the first and second floor slabs was traditional loose bar with 'hookand-bob links' for shear resistance around the columns (Bailey 2002).

The main aim of the fire test was to investigate the behavior of a full-scale concrete framed building subjected to a realistic compartment fire and applied static design load. This entailed (after Bailey 2002):

- investigating how the building in its entirety resisted or accommodated large thermal expansions from the heated parts of the structure (lateral thermal expansion of the floor slab in particular); 
- identifying beneficial and detrimental modes of whole building behavior that cannot be observed through standard fire tests on isolated structural elements;

- investigating the overall effects of concrete cover spalling and determining its possible significance on the behavior of the whole building; and

- comparing test results and observations from largescale fire tests with current methods of SFE design.

The fire exposure was within a fire compartment at an edge bay of the building with an area of $225 \mathrm{~m}^{2}$ between the ground and first floor, with a height of $4.25 \mathrm{~m}$. The compartment walls were structurally isolated from the concrete slab and columns to prevent them from influencing the structural response to the fire. One internal column was exposed to the fire and eight additional columns were partially exposed to the fire. The columns were made from high strength concrete (103 MPa compressive cube strength), so $2.7 \mathrm{~kg} / \mathrm{m}^{3}$ of polypropylene fibers were added to the concrete mix to prevent explosive spalling of the columns. The cover to all internal steel reinforcement was specified as $20 \mathrm{~mm}$. The structure was loaded during testing using sand bags, and the fire consisted of timber cribs with a load of $40 \mathrm{~kg} / \mathrm{m}^{2}$.

Full details of the test and its results are not provided here; however the following key observations and conclusions were made (after Bailey 2002):

- A maximum gas phase temperature of $950^{\circ} \mathrm{C}$ was recorded 25 minutes after ignition, after which point the instrumentation was lost (the temperature was considered 'likely' to have continued rising).

- Gas temperatures were reduced between 12 and 13 minutes due to explosive spalling of the soffit of the floor slab. The spalling of the slab's soffit was extensive and reduced the severity of the fire throughout the test and exposed the bottom reinforcing bars. Spalling was explosive and likely exacerbated by high in-plane compressive stresses in the slab caused by restraint to thermal expansion.

- Vertical displacements towards the edge of the building were larger than the displacements near the centre and showed no signs of a stabilizing plateau.

- The slab remained stable and supported the load "by compressive membrane action at small slab vertical displacement'. It should be noted however that compressive membrane action can only occur at small displacements, and thus if the slab's vertical displacements were greater or lateral restraint surrounding the heated slab were less then, as noted by Bailey (2002), 'it is difficult to see how the slab could have supported the static load'.

- Lateral thermal expansion of the slab resulted in considerable lateral displacement of the external columns; as has been identified as the cause of previous failures of concrete structures during fires.

\section{BRE Hollow-Core Slab Fire Test (2007)}

Two large-scale non-standard structural fire tests were performed by BRE at Middlesbrough, UK, to study the performance of hollowcore concrete slabs on steel beam flooring systems (Bailey and Lennon 2008). These tests were performed in the wake of worrying results from tests (Van Acker 2003) and incidences of failures of hollowcore slabs during real building fires in Europe (De Feijter and Breunese 2007). The BRE tests were intended to understand whether tying together and grouting of hollowcore slabs in a floor plate is sufficient to prevent premature shear failure which has been witnessed in small scale tests on hollowcore elements, and therefore to provide practical design guidance without the need for expensive and unnecessary tying.

Both tests had hollowcore floor plates supported on protected steelwork and they were identical except for the connection details between the hollowcore units and the supporting steel beams; the second test had a more robust detail to tie the hollowcore units and beams together. The fire compartment was $7.0 \mathrm{~m} \times 17.8$ $\mathrm{m}$ in plan and had a height of $3.6 \mathrm{~m}$. Fifteen $1200 \mathrm{~mm}$ wide $\times 200 \mathrm{~mm}$ deep standard hollowcore slabs with a concrete compressive strength of $85 \mathrm{MPa}$, and a relatively low moisture content of $2.8 \%$ by mass at the time of testing, were placed in a single row to form the roof of the fire compartment.

In Test 1 the hollowcore slabs sat directly on the supporting steel beams and the joints between the units and the gaps around the columns and units were grouted. In Test 2, U-shaped steel bars were placed in the cores and looped around shear studs fixed to perimeter beams. The cores were then grouted, as were the ends of the slab, the gaps between the slabs, and the gaps between the units and the columns. The slabs were uniformly loaded with sandbags and exposed to a natural fire using $32.5 \mathrm{~kg} / \mathrm{m}^{2}$ of evenly distributed wooden cribs. The intent was to follow the ISO 834 curve for the first 60 minutes of fire exposure.

The primary observations and conclusions were that (after Bailey and Lennon 2008):

- properly designed and detailed hollowcore floor systems have inherent fire resistance and behave very well when subjected to severe fire scenarios (i.e. more 'severe' than a standard fire);

- the maximum average gas phase temperature was greater than $1000^{\circ} \mathrm{C}$ in both tests;

- the hollowcore floor performed well during the cooling phase of the fire, and the applied load was supported for the full duration; 
- the edge units fractured locally during the cooling phase of the fire but this did not lead to loss of overall load bearing capacity;

- there was no significant spalling of the units;

- different end restraint conditions did not affect the measured vertical displacement, however restraint conditions in Test 2 kept the outer proportion of the edge slab in place when it fractured along its length; and

- there was evidence of a lateral compressive strip forming at the ends of the units caused by restraint to thermal expansion which would have enhanced the flexural, and possibly shear, capacity of the units.

\section{Hong Kong Fire Test (2010)}

A large-scale non-standard fire test on unloaded concrete columns was performed in a real building in Hong Kong in August 2010 (Wong and Ng 2011). The purpose of this test was apparently to study the effects of water quenching on the fire performance of high strength concrete in a building fire. The tests were interested specifically in various grades of high strength concrete local to Hong Kong, in the effects of spalling of various grades of concrete with or without polypropylene fibers or wire mesh reinforcement, and in the effects of passive protective coatings on enhancing the fire resistance of concrete structures.

Forty unloaded concrete columns of various types were placed inside a 'converted concrete pump house' structure which had been converted into a fire testing chamber, and were subjected to a very severe pool fire. The key conclusion of the research project was that in order to prevent spalling in high strength concrete columns, insulating or fire-resisting coating materials should be used to restrict the heat transferred into the concrete or polypropylene fibers or wire mesh should be provided in column members. These tests are inapplicable to real fires in real buildings. The testing methods employed in this study are unorthodox, even for nonstandard structural fire testing.

\section{CCAA-CESARE Fire Test (2010)}

Cement, Concrete and Aggregates Australia (CCAA 2010) have reported a single large-scale non-standard fire test on high strength concrete columns and posttensioned concrete slabs. The purpose of the test was to understand the fire performance of post-tensioned slabs and high strength concrete columns made from concrete using common Australian aggregates (with aggregate type being a known risk factor for explosive spalling). As such, the tests aimed to assess the magnitude and extent of spalling in a 'real' fire and to provide guidance on possible measures to limit its effects.
Twelve columns and three post-tensioned slabs were tested in a single fire enclosure. The columns differed in terms of concrete compressive strength, aggregate type, and the use of polypropylene fibers in the concrete mix. Columns were pre-compressed using a tensioned internal steel bar which was anchored at the column ends to simulate the compressive loading to be expected in a real multi-storey concrete building (although it is the opinion of the authors of the current paper that this is a fairly poor representation of such a scenario). The three post-tensioned slabs tested in this study differed only in terms of aggregate type.

The fire test was accomplished by placing the columns inside a plasterboard enclosure with internal dimensions of $4.25 \mathrm{~m} \times 5.4 \mathrm{~m}$ in plan $\times 3.3 \mathrm{~m}$ high. The posttensioned slabs were placed to form the roof of the enclosure. The fire load consisted of $124 \mathrm{~kg} / \mathrm{m}^{2}$ of wooden cribs, resulting in gas phase temperatures which exceeded $1000^{\circ} \mathrm{C}$ after about 45 minutes. From this test, the authors concluded that (CCAA 2010):

- the addition of fibers to the high strength mix has a dramatic effect in reducing the level of spalling (suggesting that a comparatively low dosage rate of $1.2 \mathrm{~kg} / \mathrm{m}^{3}$ is appropriate);

- the placement of column ties at closer spacing does not reduce the level of spalling (which contradicts prior research in this area);

- the post-tensioned slab containing one particular aggregate type spalled badly and hence consideration should be given to incorporating polypropylene fibers for this type of construction; and

- one of the post-tensioned slabs exhibited no spalling whatsoever whereas an identical slab spalled at both ends; no explanation was provided.

\section{TU Vienna Fire Tests (2011)}

Ring et al. (2011) present limited results of four largescale non-standard fire tests on 'frame-like' concrete structures performed to investigate the redistribution of loading within reinforced concrete structures subjected to fire (with a stated interest in tunnels). The tests were explicitly designed to provide data for the development, assessment, and validation of numerical tools for predicting the structural fire response of concrete tunnel structures.

The frames were triangular and tubular in shape and were constructed on an exterior soil slope (refer to the source publication for figures of the unusual test structures) and was loaded during testing to simulate a soil overburden. Two of the frames were made from concrete incorporating polypropylene fibers and two were constructed without fibers. The fire load was supplied to the inside of the triangular tubes, with the bottom 
of the tubes insulated, using oil-burners following a pre-specified temperature history that rose to $1200^{\circ} \mathrm{C}$ in nine minutes and remained at $1200^{\circ} \mathrm{C}$ for three hours.

The results of these tests are not particularly helpful in terms of fire resistance of buildings, although they do provide data for validation of computational models and they again demonstrate the well known benefits of incorporating polypropylene fibers to prevent explosive spalling in fire.

\section{Timber-framed buildings}

It appears that only one large-scale non-standard structural fire test of a timber structure has ever been presented in the literature, and even this is of limited interest from a structural load bearing point of view. Lennon et al. (2000) present results from a large-scale compartment fire test conducted within a full-scale six-storey timber frame building, again at BRE's Cardington test site, in September 1999. The purpose of the test was to evaluate and demonstrate the performance of medium-rise timber frame buildings subject to real fires.

The fire was provided by uniformly distributed timber cribs and was imposed within a single apartment on the third storey of the building. Flame spread was uninhibited and ventilation was arranged so as give the worst case fire severity. A key test objective was to evaluate the effectiveness of fire compartmentation in preventing fire spread from the compartment of origin to adjoining compartments and in maintaining the integrity of the evacuation routes and structural stability (Lennon et al. 2000). Full details of the test are omitted here, but the following general conclusions were drawn:

- The performance of the complete timber frame building subject to a real fire was at least equivalent to that which would have been obtained from standard fire tests on its individual elements.

- Timber frame construction can meet the functional requirements of the UK Building Regulations in terms of limiting internal fire spread and maintaining structural integrity.

- The standard of workmanship is of crucial importance in providing the necessary fire resistance performance especially nailing of plasterboards, and in ensuring the correct location of cavity barriers and fire stopping.

A series fire tests on a single-storey timber building has also been presented by Peng et al. (2011), although these did not result in any conclusions of significance for structural fire engineering.

\section{Large-scale Non-standard fire testing facilities}

A number of dedicated fire testing facilities are available globally that can be used to conducted large-scale nonstandard fire tests, and a number of new facilities have recently been completed, are under construction, or are in the planning stages; these can be divided into (1) real fire test facilities, (2) unusual, custom made, or modified fire testing furnaces, and (3) facilities under construction or in the planning stages.

\section{Real fire test facilities}

A number of 'real fire' testing facilities are available globally. In addition to the numerous outdoor test sites which have been used to perform large-scale nonstandard structural fire tests in recent years (e.g. British Steel British Steel 1999, Chlouba et al. 2009, Wald 2010, Vassart and Zhao 2011, Stadler et al. 2011, Wald et al. 2011, Ring et al. 2011, Sharma et al. 2012, described previously), many government and private sector fire testing laboratories have large burn halls which can be used to perform custom made fire tests on real structures (or parts of structures) using natural fires. Examples include (in no particular order):

- the University of Victoria's CESARE fire testing facility in Australia, which houses a 15MW oxygen calorimeter for measurement of combustion products during large experimental fires (Victoria University 2011);

- the Building Research Establishment's large burn hall, which has smoke management used for determining heat release rates, in the United Kingdom (BRE 2011);

- the National Research Council of Canada's (NRCC) burn hall in Almont, Canada, which is $55 \mathrm{~m} \times 30 \mathrm{~m}$ in plan with a ceiling height of $12.5 \mathrm{~m}$ (NRCC 2011);

- the FM Global Fire Technology Laboratory, USA, which houses a large burn hall with a footprint of $3120 \mathrm{~m}^{2}$ and includes a $20 \mathrm{MW}$ fire products collector (FM Global 2009);

- Southwest Research Institute (SwRI), USA, which houses a 'state-of-the-art full-scale furnace facility and a full-scale indoor test facility' (SwRI 2011);

- the Tianjin Fire Research Institute, which apparently has a very large burn hall at its South River Test Site, China, although very few details regarding this facility and its capabilities are currently available in English (TFRI 2011); and

- the SINTEF research laboratory, Norway, which has a $590 \mathrm{~m}^{2}$ (36 m × $\left.16.5 \mathrm{~m}\right)$ burn hall with a ceiling height between $22 \mathrm{~m}$ and $28 \mathrm{~m}$ designed for all types of large-scale fire tests and able to withstand the heat and smoke load of a $12 \mathrm{~m}^{2}$ gasoline pool fire with $18 \mathrm{~m}$ high flames (SINTEF 2011). 
These real fire testing facilities typically do not have the capability of performing tests with variable or lateral structural loading, and most do not offer calorimetry or smoke management to determine heat release rates or smoke analysis for density and toxicity. The Building Research Establishment's Cardington Test Hall (British Steel 1999) is no longer available.

In addition to these real fire research facilities, many national and private sector fire research organizations have one or more standard structural testing furnaces which can be (and in many cases have been) modified to perform non-standard tests of structural elements. Furnaces of various types, sizes, and configurations are available at most of the laboratories listed above.

\section{Unusual, custom made, or modified furnaces}

A number of custom-designed furnace testing facilities are available globally which can be used to study various aspects of the response of structures and structural components to fire in a variety of non-standard ways. These may be based on existing standard fire testing furnaces or may be custom-designed from scratch and based either on gas-fired burners or on electrical heating. A few notable examples are given below.

The Fire Safety Engineering Research and Technology Centre at the University of Ulster, Northern Ireland (FireSERT), has a reconfigurable standard floor furnace which has been modified to permit testing of specimens larger than would be typical. The furnace can also test assemblies or vertical and horizontal elements.

The University Coimbra, Portugal, has a unique 'natural fire' testing rig which is capable of testing steel subframe assemblies under exposure to gas burners with the ability to spatially and temporally vary the thermal insult to loaded test assemblies (Santiago et al. 2008). Tests performed using this facility are briefly described above in Section 3.2.

An example of a system which is based on a preexisting standard testing furnace is the column testing facility at the Federal Institute for Materials Research and Testing (BAM), in Berlin, Germany. The BAM column testing facility is based on a standard column furnace, but rather than simply applying a constant axial testing load during fire, it can use a 'hybrid' substructuring system where the entire column is tested inside the furnace and measured forces are read and target displacements are controlled via simulated modeling into the substructure in real time (Korzen et al. 2010). The BAM furnace is capable of producing an ISO 834 (ISO 1999) fire on columns of up to $3.55 \mathrm{~m}$ in height. The furnace is fired by six oil burners. Six electrohydraulic control channels are used to actively control mechanical boundary conditions (two bending rotations each at top and bottom, axial displacement at the bottom, and horizontal displacement at the top). This testing methodology allows single elements to be tested in isolation while the rest of the structure is 'simulated' by actively controlling the boundary conditions in real time during the test. A similar approach has recently been taken at the National Research Council of Canada, Ottawa, Canada, where an existing standard column testing furnace has been upgraded to permit 'hybrid' testing of isolated structural elements by active control of applied loads during testing, again using coupled numerical analysis of the full structure in real time (Mostafaei 2011).

An example of a unique fire testing furnace based on electrical heating is the University of Sheffield's connection testing furnace ( $\mathrm{Yu}$ et al. 2011). This relatively small-scale facility was custom designed to allow testing of bolted steel connections at elevated temperature under the appropriate combinations of moment, shear, thrust, and rotation that would be expected in a real building in a fire. Heating is accomplished using electrical resistance heaters, and loading is applied by a relatively complicated mechanism of restraining frames and loading jacks. This allows detailed, rational studies of the response of bolted steel connections under a wide range of possible structural and thermal actions.

Probably the best example of a custom made structural testing facility which is currently available for large-scale non-standard structural fire testing is the CERIB-Promethée testing facility in Epernon, France. This facility has been operational since 2008 (Robert et al. 2009), and was developed to expand existing standard fire tests, to incorporate boundary conditions which would occur due to restraint and interaction between hot and cold zones in a real fire in a real building, and to provide validation data for thermo-mechanical simulations of real structures during fire. The facility essentially consists of a gas-fired furnace with integrated mechanical loading frames that can reproduce interactions between the parts of the structure under testing and those that are unexposed. The furnace measures 6 $\mathrm{m} \times 4 \mathrm{~m} \times 2.5 \mathrm{~m}$ (adjustable to $4.1 \mathrm{~m}$ ), although a specimen length of $10 \mathrm{~m}$ can be installed due to the modular furnace construction. Restraint and structural interactions are simulated via multi directional loading using an array of 29 hydraulic jacks with loading capacities up to $3 \mathrm{MN}$. These jacks can be actively controlled by coupling to numerical analysis of the full structure in real time (although it is not clear if this has yet been accomplished in practice). The furnace is heated by 16 gas burners and is capable of simulating various standard fires including ISO 834 (ISO 1999) and hydrocarbon curves (CEN 2002). Despite the capabilities of this furnace, it appears that relatively few of these capabilities have yet been used to produce publishable scientific 
outputs, likely because the current prescriptive SFE regulatory framework effectively discourages investment in rational testing.

\section{Facilities under construction}

In addition to the facilities noted above, a number of unique fire testing facilities are currently under construction. Notable examples are the construction of a new $9 \mathrm{~m}$ tall testing furnace at the Centre Scientifique et Technique du Bâtiment (CSTB), Paris, France, and the current large-scale extension to the National Fire Research Laboratory (NFRL) at NIST, USA.

The CSTB facility under construction, called 'Vulcain', is a particularly large, modularized and reconfigurable standard testing furnace which will be able to test walls of $3 \mathrm{~m}$ width and $9 \mathrm{~m}$ height, long span floors with a weight of up to 30 tonnes, and various combinations of walls, columns, beams, and slabs in two and three dimensions (CSTB 2011).

NIST's extension to the NFRL will create a unique 'real fire' testing facility which will combine most of the best aspects of available testing facilities elsewhere (NIST 2011). The facility will combine the capability to test large-scale multiple bay, multi-storey structures, subject to real fires with real fuel loads, while applying controlled loads both vertically and laterally and providing data on heat release rates and gas analysis. The test area will consist of an $18.3 \mathrm{~m} \times 27.4 \mathrm{~m}$ strong floor with an adjacent $9.1 \mathrm{~m}$ high $\times 18.3 \mathrm{~m}$ wide concrete strong wall. The strong wall will act to stabilize a test specimen to prevent uncontrolled failure, to provide lateral restraint, or to laterally load a structure to simulate earthquake damage. A $13.7 \mathrm{~m}$ $\times 15.2$ m overhead hood will provide heat release rate calorimetry data up to fires $20 \mathrm{MW}$ in size (NIST 2011). It is not currently clear what specific testing is planned for this facility once operational.

\section{Knowledge gaps and research needs}

It is clear from the preceding sections that a considerable volume of large-scale non-standard structural fire testing has been performed in recent decades. A range of custom made structural fire engineering testing facilities have been commissioned or are currently under construction, and the SFE community appears to be actively engaging with the identified gaps in knowledge. Given the considerable research effort which has been undertaken thus far, it is worthwhile to ask where future research in structural fire engineering should be directed, particularly in light of the novel testing facilities which are soon to be available.

The following is a non-exhaustive list of knowledge gaps and research needs suggested either by previous authors or which have been identified during the preceding discussion.

\section{Fire exposure}

As noted by authors going back to (at least) 1970, the standard temperature-time curve is not representative of a real fire in a real building. In order to truly understand the response of real buildings in real fires, tests of structures and structural elements are required under credible worst case natural fire exposures. Depending on the type and geometry of structure and the occupancy under consideration, this may require experimental consideration of localized, compartmentalized, horizontally and/ or vertically travelling, smouldering, or hydrocarbon fires, all of which have the potential to introduce structural actions or interactions which are not captured by standard fires. In particular, the true dynamics of travelling or spreading fires in large compartments has received only limited attention within the research literature (e.g. Stern-Gottfried and Rein 2012), and essentially zero attention in large scale structural fire tests. There appears to be no facility in the world which is capable of producing (or reproducing) truly natural fire exposures on structures of realistic scale and construction, although the new NIST facility (Section 4.3) will go some way towards making this a reality.

\section{Structural interactions and asymmetry}

The available test data from large-scale non-standard fire tests, while extensive, still cover only a tiny fraction of the possible structural configurations that are represented within the current global building stock, let alone the highly optimized and sustainable buildings of the future. With a few notable exceptions, the majority of structural fire tests conducted to date, whether standard or non-standard, have studied regular, symmetrical, highly idealized structures. Modern structures increasingly make use of irregular floor plates with varying span lengths, bay sizes, construction types, etc. The possible influence of irregular floor plans and complex building forms needs to be investigated, both experimentally and numerically, if performance-based structural fire engineering of both conventional and modern buildings is to be credibly performed with confidence. Indeed the importance of irregular building layouts, the position of service cores, and lateral restraint to thermal expansion are already known (through computational modeling studies of real high rise buildings) to be potentially important for full-structure response to fire (e.g. Usmani et al. 2006, Flint et al. 2007, McAllister et al. 2012, Flint et al. 2013).

\section{Failure localizations}

When real structures fail in fires it is rarely for the reasons that would be expected on the basis of standard fire resistance testing. In many cases, global failure is precipitated by some form of localised failure or structural distress, such as discrete cracking in concrete, rupture of tensile 
steel reinforcement, failure of a connection, local buckling of structural steelwork, shear (punching) failure of a concrete slab, rupture of an unbonded prestressing tendon, etc. Unfortunately, the only way to observe and understand such failure localizations, which depend in virtually all cases on the three dimensional interactions between elements of structure during both heating and cooling, is to perform large-scale non-standard structural fire tests on real buildings. Only once all of the possible failure modes are known can they possibly be rationally incorporated into computational models for full structure response to fire.

\section{Compartmentation and fire spread}

To date, most large-scale structural fire testing has focused on prevention of structural collapse during fire, and relatively little attention has been paid to preservation of compartmentation under large deformations in real structures during fire; this is particularly of concern given the large floorplate deflections and wide discrete cracking which have been widely observed in large-scale fire tests on steel-concrete composite slabs (see Section 3.1). The impacts of vertical and lateral deformations of structural frames on fire stopping and on both horizontal and vertical compartmentation should be studied to preserve life safety in buildings which are now becoming ever more reliant on defend-in-place life-safety strategies (for instance in highrise buildings where fire safety strategies are typically based on the assumption that a fire will be confined to the floor of origin).

Furthermore, given that many structural fire engineers already have serious concerns about the quality of installed fire stopping between floors in multi-storey buildings, large-scale non-standard fire tests should perhaps be considered in which vertical fire spread is explicitly simulated using natural fires to evaluate the structural impacts of credible worst case fires burning simultaneously on more than one floor of a structure.

\section{Detailing and construction errors}

Taken together, the tests described in this report highlight a number of important construction details and potential construction errors which may appear inconsequential to a building contractor, but which may have a profound impact on the structural fire response and integrity of a building during fire. Examples of this include integrity of fire stopping during large deformations, lapping of steel reinforcing mesh, anchorage of steel reinforcing mesh over shear studs on protected perimeter beams, use of deformed versus smooth bars for reinforcement (potentially leading to strain localization and tensile failure of deformed steel bars during fire), proper anchorage and grouting of hollowcore slabs, use of specific types of bolted steel connections to promote connection ductility and rotational capacity during fire, quality, uniformity, and robustness of structural fire protection materials (either passive or intumescent), and so on. Serious unknowns continue to surround many, if not all, of these issues, and there is a need for testing to support the development of best practice guidance which can be used to provide quality assurance programs on construction sites of so-called 'fire engineered' buildings.

\section{Cooling phase behavior and residual capacity}

A number of localized structural failures or adverse structural responses of steel connections, concrete flat plate slabs, and hollowcore slabs have been observed during the cooling phase of both real fires in real buildings (e.g. Firehouse.com 2004, Bamonte et al. 2009) and non-standard heating regimes in large-scale structural fire experiments (e.g. Bailey and Lennon 2008, British Steel 1999). Structural actions resulting from creep, localised and/or global plastic deformation, local buckling, and thermal contraction and restraint, all need to be better understood for all types of structures if designers are to realistically be expected to design for full burnout of a fire compartment without structural collapse.

Furthermore, the residual structural capacity of fire damaged structures which have undergone large deformations is not well known, meaning that many firedamaged structures will need to be demolished after a fire (e.g. New York Times 1997). This is particularly true for so-called fire-engineered composite steel frames, which explicitly rely on large deformation behavior to mobilize the tensile membrane actions which are necessary to support gravity loads and prevent collapse during fire (British Steel 1999).

\section{Instrumentation and measurement}

Most SFE authors agree that more complete data are required from both standard and non-standard structural fire tests. Better information on strains and displacements during testing would allow a more accurate understanding of response, and would provide additional data which are essential for high quality computational model development and validation. The need for new types of sensors, such as wireless sensors to be used during fire tests, has been noted previously (Kodur et al. 2011). However, the authors of the current review feel that what is really needed is a better understanding of what is being measured; i.e. What should be measured in order to truly understand the global performance of the element of the structure being tested?

\section{Data for model calibration, validation and verification}

Experimental data are essential for calibration, validation, and verification of both existing and emerging computational modeling techniques to simulate the 
response of structures and structural elements in fire. This requirement holds both at the material level and at the structural (i.e. system) level. As noted by Kodur et al. (2011), high-temperature constitutive material models are needed to generate reliable input data for models and to better understand system response to fire and possible failure modes. Such data must be developed using an appropriate framework for understanding the stress-temperature-time-strain interrelationships at play in most engineering materials. An excellent framework for materials characterization at elevated temperature was presented more than two decades ago by Anderberg (1986), however the complexities shown in this framework are rarely explicitly acknowledged in SFE analysis or design.

\section{Structural optimization and the Use of New materials and systems}

Modern structures are highly optimized, increasingly by the use of sophisticated computer analysis, in an attempt to reduce the mass, cost, environmental impact, carbon emissions, and embodied energy in buildings (Terrasi 2007). Modern structures also increasingly make use of innovative materials, such as high strength, self consolidating concrete, fiber reinforced polymers (FRPs), structural adhesives, stainless steel, etc., and innovative structural systems such as unbonded post-tensioned flat plate concrete slabs; the responses of which during fire are not well known in many cases. New materials and structural systems must be rationally understood before they should be applied with confidence in buildings. Such an understanding demands large-scale non-standard fire testing, in particular because the standard furnace tests that were developed for conventional construction materials and systems are based on structural response and failure definitions which often are not applicable to newer innovative ones (e.g. Bisby and Kodur 2007).

\section{Connections}

As noted previously, a range of studies have already been performed on connection performance in fire (largely for steel structures) (e.g. Ding and Wang 2007, Yu et al. 2009, 2011, Yuan et al. 2011). However, given the range of possible connection types, full-structure responses to fire, and failure modes, additional research is needed to better understand the full range of possible connections, to develop and validate computational modeling capabilities to predict connection response, and to suggest best practice guidance (in particular to steel fabricators) on the types of connections which should be applied in practice to ensure structural robustness in fire. Proper details for the connection of precast concrete elements in buildings to ensure robust performance in fire is also required (Bailey and Lennon 2008). Important lessons can be learned on these issues by studying the literature and available design provisions on the seismic design of structural connections (FEMA 2000a, FEMA 2000b, AISC 2005); it may be appropriate to develop similar provisions for structural robustness in fire.

\section{Explosive spalling of concrete}

Structural fire design of modern reinforced and prestressed concrete structures relies on the assumption that the concrete will not spall during fire. This assumption is based largely on data from large-scale standard fire tests of concrete elements tested in isolation in furnaces during the past 60 to 70 years. However, there is legitimate concern (Kelly and Purkiss 2008) that modern concrete structures, which incorporate concrete mixes with considerably higher concrete strengths, are more susceptible to spalling than was historically the case. Whilst preliminary guidance on the means by which spalling can be addressed by designers is available in the structural Eurocodes (CEN 2004), research is badly needed to understand the respective roles of the various factors which are known to increase a concrete's propensity for spalling during fire (e.g. high strength, high stress, high moisture, low permeability, small amounts of bonded reinforcement, use of silica fume, rapid heating, etc.) (ArupFire 2005, Bailey and Khoury 2011), such that defensible preventative actions can be taken. For instance, more specific and defensible guidance is needed on the requirement to add a certain amount of polypropylene fibers to the concrete mix to prevent spalling. Interactions in real structures have the potential to significantly influence development of spalling in a fire, so large-scale tests under natural fires are needed to truly understand the propensity for, and the structural consequences of, spalling in real concrete structures.

\section{Timber structures}

A critical issue for the structural fire protection of timber structures appears to be the integrity of fire proofing materials such as gypsum plasterboard (Lennon et al. 2000). Additional research is required to better understand the factors leading to 'fall-off' of plasterboard and other fire stopping materials and systems during fire. It is important to recognise the difference between light timber frame buildings (where the fire resistance of wood must be protected by gypsum lining materials) and heavy timber buildings which rely on the predictable charring rate of large timber members.

Another critical issue for timber structures is the performance after the fire has gone out. Designers are often concerned that charred timber will continue to char after all flaming has ceased, which makes it difficult or impossible to design for a complete burnout as is done for concrete or steel structures. More research is needed 
in this area, and this can only be done with large scale structural fire testing.

\section{Conclusion}

This paper has presented a review of structural fire engineering research done at the large-scale around the world during the past four decades. It has identified gaps and further research needs based both on the conclusions of previous studies and also on the authors' own assessments of the information presented. Areas where particular research attention is needed include:

- non-standard fire exposures;

- structural interactions and asymmetry;

- failure modes and failure localizations;

- the effects of structural deformation on compartmentation and fire spread;

- detailing best practice and the influence of construction details on overall structural fire performance;

- cooling phase behavior and residual capacity after fire;

- functional and meaningful instrumentation and measurement during fire testing;

- development of data which are useful for model calibration, validation and verification;

- the influence of structural optimization and novel structural materials on structural fire performance;

- the performance of various types of connections during fire, particularly during the cooling phase;

- causes, prevention, and impacts of explosive concrete cover spalling; and

- the performance of both light-frame and solid timber buildings both during and after real fires.

It is hoped that the information presented in this review might help steer future research in structural fire engineering, particularly in the case of non-standard experimental research at the large-scale.

\section{Competing interests}

The authors declare that they have no competing interests.

\section{Authors' contributions}

This paper represents a true joint effort between the three listed authors. Doctoral candidates JG and CM performed the bulk of the literature search, informed through discussion with their supervisor, LB, JG and CM each created first drafts of various sections of the paper, each on an approximately 50\% basis, while LB structured the paper, added insight, and performed final editing etc. The order of authorship is therefore somewhat arbitrary, and the authors consider that all three contributed equally. All authors read and approved the final manuscript.

\section{Acknowledgments}

The authors would like to acknowledge the generous support of Kathleen Almand and the Fire Protection Research Foundation. We would also like to thank the School of Engineering at the University of Edinburgh, which is part of the Edinburgh Research Partnership in Engineering and Mathematics, The Ove Arup Foundation, The Natural Science Engineering Research Council of
Canada, The UK Royal Academy of Engineering and The Lloyd's Register Educational Trust.

\section{Author details}

${ }^{1}$ Arup Professor of Fire and Structures, BRE Centre for Fire Safety Engineering, The University of Edinburgh, UK EH9 3JL. ${ }^{2}$ BRE Centre for Fire Safety Engineering, The University of Edinburgh, UK EH9 3JL.

Received: 6 January 2013 Accepted: 8 April 2013

Published: 21 May 2013

\section{References}

Anon (1986) brandverhalten von stahl und stahlverbund construction (Fire behaviour of steel and composite construction). Verlag, TUV, Rheinland

AISC (2005) ANSI/AISC 341-05 - Seismic Provisions for Structural Steel Buildings. American Institute of Steel Construction (AISC), Chicago

Almand K, Phan L, McAllister T, Starnes M, Gross J (2004) NISTIR 7133: SFPE Workshop for Development of a National R\&D Roadmap for Structural Fire Safety Design and Retrofit of Structures. National Institute of Standards and. Technology, Gaithersburg

Anderberg Y (1986) Modelling steel behaviour. Paper presented at the International Conference on Design of Structures Against Fire. Aston University, Birmingham, pp 15-16, 15-16 April 1986

Annerel E, Lu L, Taerwe L (2011) Punching shear tests on flat concrete slabs at high temperatures. Proceedings of the $2^{\text {nd }}$ International RILEM Workshop on Concrete Spalling due to Fire Exposure. RILEM Publications S.A.R.L., Delft, pp 125-131, 5-7 October 2011

ArupFire (2005) Fire resistance of concrete enclosure - Work package 2: Spalling categories. Authored for the Nuclear Safety Directorate of the Health and Safety Executive (HSE). Arup Group Ltd, London

ASTM (1980) ASTM E119: Fire Tests of Building Construction and Materials. American Society for Testing and Materials, Philadelphia, PA

ASTM (2011) ASTM E119-11a: Standard methods of fire test of building construction and materials. American Society for Testing and Materials, West Conshohocken

Bailey CG (2002) Holistic behaviour of concrete buildings in fire. Struct Build 152 (3):199-212. doi:10.1680/stbu.2002.152.3.199

Bailey CG, Toh WS (2007) Behaviour of concrete floor slabs at ambient and elevated temperature. Fire Safety Journal 42(6-7):425-436. doi:10.1016/j. firesaf.2006.11.009

Bailey CG, Lennon T (2008) Full scale fire tests on hollowcore slabs. The Structural Engineer 86(6):33-39

Bailey CG, Khoury GA (2011) Performance of Concrete Structures in Fire - An indepth publication on the behaviour of concrete in fire. Ruscombe Printing Ltd, Reading, Surrey, UK

Bamonte P, Felicetti R, Gambarova PG (2009) Punching Shear in Fire-Damaged Reinforced Concrete Slabs. ACI Special Publication 265. American Concrete Institute, Farmington Hills, pp 345-366

Beitel J, Iwankiw N (2008) NIST GCR 02-843-1 (Revision) - Analysis of Needs and Existing Capabilities for Full-Scale Fire Resistance Testing. National Institutes for Standards and Technology, Gaithersburg

Beyler C, Beitel J, Iwankiw N, Lattimer B (2007) NIST GCR 07-910 - Fire resistance testing for performance-based fire design of buildings. National Institute of Standards and Technology, Gaithersburg

Bisby LA, Kodur VKR (2007) Evaluating the fire endurance of concrete slabs reinforced with FRP bars: Considerations for a holistic approach. Composites Part B: Engineering 38(5-6):547-558. doi:10.1016/j.compositesb.2006.07.013

BRE (2011) Fire Test Facilities., Available via http://www.bre.co.uk/page.jsp?id=417. Accessed 7 December 2011

British Steel (1999) The behaviour of multi-storey steel frame buildings in fire. British Steel, Rotherham

Buchanan A (2001) Structural design for fire safety. Wiley, West Sussex, UK

Cadorin JF, Pintea D, Franssen JM (2001) The Design Fire Tool OZone V2.0 - Theoretical Description and Validation On Experimental Fire Tests. University of Liege, Belgium

CCAA (2010) Fire Safety of Concrete Buildings. Cement Concrete \& Aggregates Australia, St Leonards, Australia

CEN (2002) BS EN 1991-1-2:2002 - Eurocode 1: Actions on structures - Part 1-2: General actions - Actions on structures exposed to fire. European Committee for Standardization, Brussels

CEN (2004) BS EN 1992-1-2:2004 - Eurocode 2: Design of concrete structures Part 1.2: General rules - Structural fire design. European Committee for Standardization, Brussels 
Chlouba J, Wald F (2009) Connection temperatures during the mokrsko fire test. Acta Polytechnica 49(1):76-81

Chlouba J, Wald F, Sokol Z (2009) Temperature of connections during fire on steel framed building. International Journal of Steel Structures 9(1):47-55. doi:10.1007/BF03249479

Chung H-Y, Lee C-H, Su W-J, Lin R-Z (2010) Application of fire-resistant steel to beam-to-column moment connections at elevated temperatures. Journal of Constructional Steel Research 66:289-303. doi:10.1016/j.jcsr.2009.09.009

Cooke GME, Latham DJ (1987) The inherent fire resistance of a loaded steel framework. Steel Construction Today 1:49-58

Corus (2006) Fire resistance of steel-framed buildings. Corus Construction and Industrial, Scunthorpe

CSTB (2011) Vulcain., Available via http://www.cstb.fr/le-cstb/equipements/feu/ vulcain.html. Accessed 1 December 2011

De Feijter MP, Breunese MP (2007) 2007-Efectis-R0894(E) - Investigation of Fire in the Lloydstraat Car Park, Rotterdam. Effectis Nederland BV, The Netherlands

Ding J, Wang YC (2007) Experimental study of structural fire behaviour of steel beam to concrete filled tubular column assemblies with different types of joints. Eng Struct 29(12):3485-3502. doi:10.1016/j.engstruct.2007.08.018

Dong Y, Prasad K (2009a) Thermal and structural response of a two-story, two bay composite steel frame under fire loading. Proc Combust Inst 33:2543-2550. doi:10.1016/j.proci.2008.05.007

Dong Y, Prasad K (2009b) Experimental study on the behavior of full-scale composite steel frames under furnace loading. J Struct Eng 135(10):1278-1289. doi:10.1061/(ASCE)0733-9445(2009)135:10(1278)

FEMA (2000a) FEMA-350 - Recommended Seismis Design Criteria for New Steel Moment-Frame Buildings. Federal Emergency Management Agency, Hyattsville, USA

FEMA (2000b) FEMA-3555D - State of the Art Report on Connection Performance. Prepared for the SAC Joint Venture Partnership. Federal Emergency Management Agency, Hyattsville, USA

Firehouse.com (2004) Seven Swiss firefighters die in collapsed parking garage., Available via http://www.firehouse.com/news/lodd/seven-swiss-firefightersdie-collapsed-parking-garage. Accessed 6 December 2011

Flint G, Lamont S, Lane B, Sarrazin H, Lim L, Rini D, Roben C (2013) Recent lessons learned in structural fire engineering for composite steel structures. Fire Technology, published online ahead of print. doi:10.1007/s10694-0120291-8

Flint G, Usmani A, Lamont S, Lane B, Torero J (2007) Structural response of tall buildings to multiple floor fires. J Struct Eng 133(12):1719-1732. doi:10.1061/ (ASCE)0733-9445(2007)133:12(1719)

FM Global (2009) The FM Global Research Campus. FM Global, USA

Gillie M (2009) Analysis of heated structures: nature and modelling bench marks. Fire Safety Journal 44(5):673-680. doi:10.1016/j.firesaf.2009.01.003

Grosshandler WL (2002) NISTIR 6890 - Fire Resistance Determination and Performance Prediction Research Needs Workshop. National Institute of Standards and Technology, Gaithersburg

Grosshandler WL (2003) The international FORUM of fire research directors: A position paper on evaluation of structural fire resistance. Fire Safety Journal 38:645-650. doi:10.1016/50379-7112(03)00068-7

Han L-H, Wang W-H, Yu H-X (2010) Performance of RC Beam to Concrete Filled Steel Tubular (CFST) Column Frames Subjected to Fire. Proceedings of the $6^{\text {th }}$ International Conference on Structures in Fire. Michigan State University, East Lansing, pp p 358-365, 2-4 June 2010

Harmathy TZ, Lie TT (1970) Fire Test Standard in the Light of Fire Research, Fire Test Performance - ASTM STP 464. American Society for Testing and Materials, Philadelphia, pp 85-97

ISO (1999) ISO 834-1:1999: Fire Resistance Tests - Elements of Building Construction - Part 1: General Requirements. International Organization for Standardization, Geneva

Jeanes D (1982) Predicting fire endurance of steel structures. National ASCE Convention, Las Vegas, pp 82-033, April 26-30. Preprint pgs

Joyeux D, Kruppa J, Cajot LG, Schleich JB, Van de Leur P, Twilt L (2001) Demonstration of real fire tests in car parks and high buildings, CEC Agreement 7215-PP/025. CTICM, France - Profil-ArbedReceherches, Luxembourg - TNO, The Netherlands

Kelly F, Purkiss J (2008) Reinforced concrete structures in fire: a review of current rules. The Structural Engineer 86(19):33-39

Kodur VKR, Garlock MEM, Iwankiw N (2007) NISTGCR 07-915 - Structures in fire: state of the art, research and training needs. National Institute of Standards and Technology, Gaithersburg
Kodur VKR, Garlock MEM, Iwankiw N (2011) Structures in fire: State of the art, research and training needs. Fire Technol 48(4):825-839. doi:10.1007/s10694011-0247-4

Kordina K (1997) Ueber das brandverhaltem punkthestuetzter stahlbetonplatten (Investigations on the behaviour of flat slabs under fire). DAfsib H 479:106S

Korzen M, Rodrigues J, Correia A (2010) Composite columns made of partially encased steel sections subjected to fire. Proceedings of the $6^{\text {th }}$ International Conference on Structures in Fire. Michigan State University, East Lansing, pp p 341-348, 2-4 June 2010

Law M (1981) Designing fire safety for steel - recent work. Proceedings of the ASCE Spring Convention. American Society of Civil Engineers, New York, 11-15 May 1981

Lennon T, Bullock MJ, Enjily V (2000) The fire resistance of medium-rise timber frame buildings. World Conference on Timber Engineering, Whistler, Canada, 31 July-3 August 2000

Li-tang G, Li X, Chen L, Yuan A (2008) Experimental investigation of the behaviours of unbonded prestressed concrete continuous slabs after fire. Concrete (in Chinese), 2008-02

McAllister TP, Gross JL, Sadek IH, Kirkpatrick SW, MacNeill RS, Zarghamee MS, Erbay OO, Sarawit AT (2012) Structural Response of World Trade Center Buildings 1, 2 and 7 to Impact and Fire Damage. National Institute of Standards and Technology, Gaithersburg

Mostafaei H (2011) RR-316 - Hybrid Fire Testing for Performance Evaluation of Structures in Fire - Part 1: Methodology. National Research Council of Canada, Ottawa, 26 August 2011

Nadjai A, Bailey CG, Vassart O, Han S, Zhao B, Franssen JM, Simms I (2011) Full-scale fire test on a composite floor slab incorporating long span cellular steel beams. The Structural Engineer 89(21):18-25

New York Times (1997) Philadelphia to Raze Site of High-Rise Fire., Available via http://www.nytimes.com/1997/11/14/us/philadelphia-to-raze-site-of-high-risefire.html. Accessed 7 December 2011

NIST (2011) Project: National Fire Research Laboratory Commissioning and Operations., Available via http://www.nist.gov/el/fire_research/nfrl/ project_nfrl.cfm. Accessed 5 December 2011

NRCC (2011) Burn Hall - Three Storey Exterior Wall Test Facility., Available via http:/ archive.nrc-cnrc.gc.ca/eng/facilities/irc/burn-hall.html. Accessed 9 December 2011

Proe D, Bennetts I (1994) Real Fire Test in 380 Collins Street Office Enclosure. BHP Research Report No. BHPR/PPA/R/051/SG021A. BHP Billiton Limited, Melbourne

Proe D, Thomas I (2010) Planning for a Large-Scale Fire Test on a Composite SteelFrame Floor System. Proceedings of the $6^{\text {th }}$ International Conference on Structures in Fire. Michigan State University, East Lansing, pp p 390-397, 2-4 June

Peng W, Hu L-H, Yang R-X, Lv Q-F, Tang F, Xu Y, Wang L-Y (2011) Full scale test on fire spread and control of wooden buildings. Procedia Engineering (in Chinese) 11:355-359

Ring T, Zeiml M, Lackner R (2011) Large scale fire tests on concrete design and results. Poster presented at the 18th Inter-Institute Seminar for Young Researchers, Budapest, Hungary, pp 23-25, September 2011

Robert F, Rimlinger S, Collet E, Collignon C (2009) PROMETHEE, The innovative fire resistance testing centre for structures. International Conference on Applications of Structural Fire Engineering, Prague, Czech Republic, pp 19-21, February 2009, Annex 14

Rubert A, Schaumann P (1986) Structural steel and plane frame assemblies under fire action. Fire Safety Journal 10(3):173-184. doi:10.1016/0379-7112(86)90014-7

Santiago A, da Silva LS, Vaz G, Vila Real P, Lopez AG (2008) Experimental investigation of the behaviour of a steel sub-frame under a natural fire. Steel and Composite Structures 8(3):243-264

Sharma UK, Bhargava P, Singh B, Singh Y, Kumar V, Kamath P, Usmani A, Torero J, Gillie M, Pankaj P, May I, Zhang J (2012) Full scale testing of a damaged RC frame in fire. Struct Build 165(7):335-346. doi:10.1680/stbu.11.00031

SINTEF (2011) Large test hall., Available via http://www.sintef.no/home/Buildingand-Infrastructure/SINTEF-NBL-as/About-SINTEF-NBL/Laboratories/Large-testhall/. Accessed 9 December 2011

Stern-Gottfried J, Rein G (2012) Travelling fires for structural design. Part II: design methodology. Fire Safety Journal 54:96-112. doi:10.1016/j.firesaf.2012.06.011

SwRI (2011) Fire Testing Services., Available via http://www.swri.org/4org/d01/ fire/fireres/home.htm. Accessed 5 December 2011

Stadler M, Mensinger M, Schaumann P, Sothmann J (2011) Munich fire tests on membrane action of composite slabs in fire - test results and recent findings. Proceedings of the international conference on applications of structural fire engineering, Prague. Czech Republic 29:177-182, April 2011

Terrasi GP (2007) Prefabricated Thin-walled Structural Elements made from HPC Prestressed with Pultruded Carbon Wires. Proceedings of the $8^{\text {th }}$ 
International Symposium on Fiber Reinforced Polymer Reinforcement for Concrete Structures. University of Patras, Greece, 16-18 July 2007

TFRI (2011) I hold China-US fire protection technology and fire codes academic exchange activities., Available via http://www.tfri.com.cn/manage/html/index. html (in Chinese). Accessed 9 December 2011

Thomas IR, Bennetts ID, Dayawansa PH, Proe DJ, Lewins RR (1992) Fire Tests of the 140 William Street Office Building, BHP Research Report No. BHPR/ENG/ R/92/043/SG2C. BHP Billiton Limited, Melbourne

Troxell GE (1959) Fire resistance of a prestressed concrete floor panel. Journal of the American Concrete Institute 56(8):97-105

Usmani A, Roben C, Johstone L, Flint G (2006) Tall building collapse mechanisms initiated by fire. SiF'06. Proceedings of the 4th International Workshop Structures in Fire, East Lansing, Michigan, 2-4 June 2010

Van Acker A (2003) Shear resistance of prestressed hollow core floors exposed to fire. Struct Concr 4(2):65-74. doi:10.1680/stco.2003.4.2.65

Van Herberghen P, Van Damme M (1983) Fire resistance of post-tensioned continuous flat floor slabs with unbonded tendons. FIP Notes, UT, pp 3-11

Vassart O, Zhao B (2011) FRACOF Engineering Background. Report developed for the Leonardo Da Vinci Programme: Fire Resistance Assessment of Partially Protected Composite Floors (FRACOF). European Commission, Education and Culture DG, Bordeaux, France

Victoria University (2011) Fire test facilities., Available via http://www.vu.edu.au/ centre-for-environmental-safety-and-risk-engineering-cesare/fire-test-facilities. Accessed 7 December 2011

Wald F, Simões da Silva L, Moore DB, Lennon T, Chaldna M, Santiago M, Beneš $M$, Borges L (2006) Experimental behaviour of a steel structure under natural fire. Fire Safety Journal 41(7):509-522. doi:10.1016/j.firesaf.2006.05.006

Wald F (2010) Fire Test on an Administrative Building in Mokrsko. Czech Technical University, Printing house Česká technika, Prague, Czech Republic

Wald F (2011) Large Scale Fire Tests. COST Action TU0904. Integrated Fire Engineering and Response Working Group, Prague, Czech Republic, April 30

Wald F, Jána T, Horová K (2011) Design of joints to composite columns for improved fire robustness - To demonstration fire tests. Czech Technical University, Printing house Česká technika, Prague, Czech Republic

Wong YL, Ng YW (2011) Technical Seminar - Effects of Water Quenching on Reinforced Concrete Structures under Fire. Presented to The Institution of Fire Engineers (Hong Kong Branch). Kowloon Tong Fire Station, Kowloon, 23 August 2011

Wong SY, Burgess IW, Plank RJ, Atkinson GA (1999) The response of industrial portal frames to fires. Acta Polytechnica 39(5):169-182

Yu H, Burgess I, Davison J, Plank R (2011) Experimental and numerical investigations of the behavior of flush End plate connections at elevated temperatures. J Struct Eng 137(80):80-87. doi:10.1061/(ASCE)ST.1943$541 \times .0000277$

Yu H, Burgess IW, Davison JB, Plank RJ (2009) Experimental investigation of the behaviour of fin plate connections in fire. Journal of Constructional Steel Research 65(3):723-736. doi:10.1016/j.jcsr.2008.02.015

Yuan Z, Tan KH, Ting SK (2011) Testing of composite steel top-and-seat-and-web angle joints at ambient and elevated temperatures: Part 2 - Elevatedtemperature tests. Eng Struct 31(9):2093-2109. doi:10.1016/j. engstruct.2011.02.021

Zhao JC, Shen ZY (1999) Experimental studies of the behaviour of unprotected steel frames in fire. Journal of Constructional Steel Research 50:137-150. doi:10.1016/S0143-974X(98)00246-6

Zheng WZ, Hou XM, Shi DS, Xu MX (2010) Experimental study on concrete spalling in prestressed slabs subjected to fire. Fire Safety Journal 45:283-297. doi:10.1016/j.firesaf.2010.06.001

doi:10.1186/2193-0414-2-1

Cite this article as: Bisby et al: A contemporary review of large-scale non-standard structural fire testing. Fire Science Reviews 2013 2:1.

Submit your manuscript to a SpringerOpen ${ }^{\odot}$ journal and benefit from:

- Convenient online submission

- Rigorous peer review

- Immediate publication on acceptance

- Open access: articles freely available online

- High visibility within the field

- Retaining the copyright to your article

Submit your next manuscript at $\gg$ springeropen.com 